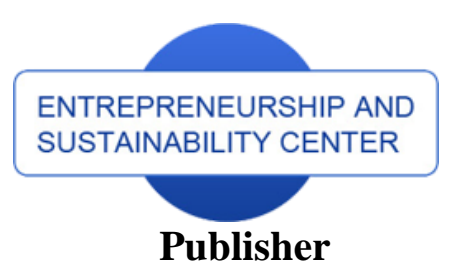

http://jssidoi.org/esc/home

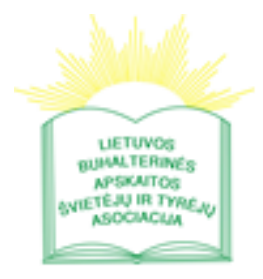

enterprise

* europe network

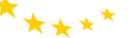

Business Support on Your Doorstep
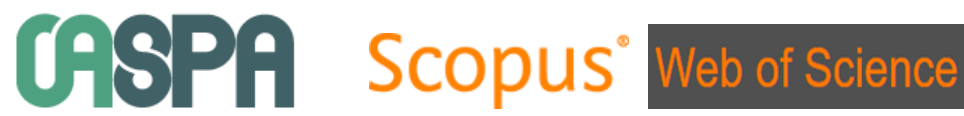

\title{
STRUCTURED LITERATURE REVIEW ON BUSINESS PROCESS PERFORMANCE ANALYSIS AND EVALUATION
}

\author{
Jolanta Zemguliene ${ }^{1}$, Mantas Valukonis ${ }^{2}$ \\ ${ }^{1}$ Faculty of Economics and Business Administration, Vilnius University, Sauletekio 9 Vilnius, Lithuania \\ ${ }^{2}$ Kaunas Faculty, Vilnius University, Muitinès 8 Kaunas, Lithuania \\ E-mail:. ${ }^{\text {jolanta.zemguliene@ef.vu.lt, }{ }^{2} \text { mantas.valukonis@knf.vu.lt }}$
}

Received 3 March 2018; accepted 10 June 2018; published 30 September 2018

\begin{abstract}
Knowledge of business process analysis instruments and methods enhance the possibility to quantify process management decisions and to achieve organizations' goals. While the amount of research on business process analysis and evaluation increases, there is a need to outline the intellectual structure of scientific research as embodied in business process scientific literature in order to define the streams of research. The purpose of this paper is to present actionable knowledge of business process performance analysis and evaluation, based on the framework, integrating business process research domains and levels of analysis. In order to establish a framework, integrating the domains of business process analysis, the research questions were formulated and the analysis of the scientific literature was carried out applying the method of structured literature review. Literature review was based on a research papers that were available through the EBSCO host, Academic search complete databases. References were searched using the keywords that are formed as combinations of words: business process, analysis, performance, evaluation. Research contributions, addressing the business process analysis topic, were selected by the keywords within the papers' title, abstract and in the keywords specified in the article. After the initial evaluation of 677 papers, 62 articles were selected for in-depth analysis. This paper contributes to the business process management research by proposing the framework to integrate various business process analysis research streams and highlighting exploratory potential areas for future inquiry.
\end{abstract}

Keywords: business process; business process performance; process evaluation; business process performance indicators

Reference to this paper should be made as follows: Zemguliene, J.; Valukonis, M. 2018. Structured literature review on business process performance analysis and evaluation, Entrepreneurship and Sustainability Issues 6(1): 226-252. http://doi.org/10.9770/jesi.2018.6.1(15)

JEL Classifications: M11 


\section{Introduction}

Business process capability to deliver the output that fits the requirements of the efficient use of process resources and the needs of the customer is recognized to be the basis for the overall development of business organization and capability to achieve the competitive advantage. Organizations based on horizontal end-to-end processes have been shown to increase the quality of products and services, decrease costs and make business functions more reliable (Khosravi, 2016). Therefore, the issue how the improvement in business process capability should be achieved is discussed in voluminous business process studies and reports. Business process reengineering, business process management and business process improvement approaches provide various models, methods and techniques designed to develop the business process. Most of them involve process analysis as the distinctive point in the execution of process improvement. Davenport and Short (1990), Hammer and Champy (1993), defining the business process reengineering, emphasized the analysis of workflows and processes as the initial step for radical process redesign. Dumas et al. (2013) provided business process management method which is typically designed to explore existing processes and provide the relevant information for process improvement decisions. This method describes the steps of process management by process identification, discovery, analysis, redesign, implementation, monitoring and controlling. Van der Aalst (2004) identified the importance of business process analysis in business process management systems and also noted that process workflow management systems lack the tools for the process analysis and do not support the use of the data, logged by the information system to diagnose the operational processes.

Process analysis provides the tools to understand the sources of the problems of process accomplishment, to discover the possible ways of process improvement and optimization and also the measures of performance assessment (Irani et al., 2002). Much has been discussed on business process analysis in the literature. Vergidis et al. (2006) providesd an overview on business process analysis, underlinesd types of process analysis in relation to the different business process modeling techniques. Li et al. (2004) proposed the framework for the process workflow analysis, which involved the perspectives of logical level, temporal level and performance level. Bisogno et al. (2016) proposed a method for the analysis of business process operational performance. This model is applicable for what-if analysis. Various studies provide different models and frameworks designed to enable process analysis. They describe process' features and properties and explore process domains in relation to the purpose of analysis. As Aguilar-Saven (2004) identified "purpose of business analysis is either to learn about the process, to make decisions about the process or to develop business process". Furthermore, purpose of the analysis is coherent to the perspective of the analysis.

Process level perspective is associated to the knowledge of the processes, whereas process analysis from the operation level perspective generate the knowledge of the process' impact on the operation's and enterprise performance, process is a unit in the enterprise' set of processes. Due to popularity of business process orientation in various business settings, a number of business process analysis methods and techniques to support process building and management were provided in the literature. While the attempts to generalize the process evaluation methods were provided, there is a lack of guide that organizes methods for business process analysis according to perspective of analysis. Generalization of business process analysis' perspectives support systematization of the knowledge in the area of business process analysis and provide insights of the areas of potential enquiry in this field. 
The International Journal

ENTREPRENEURSHIP AND SUSTAINABILITY ISSUES

ISSN 2345-0282 (online) http://jssidoi.org/jesi/

2018 Volume 6 Number 1 (September)

http://doi.org/10.9770/jesi.2018.6.1(15)

The purpose of this paper is to present a framework of business process performance analysis and evaluation, integrating business process constructs and levels of analysis. The following questions are addressed in this paper:

(1) What are the main research questions considered in the research on business process elements and properties?

(2) What are the main trends in the research on business process performance analysis?

\section{Elements, structure and properties of business process}

Voluminous business process definitions, provided in the literature, emphasize the interrelated activities as the basic element of the business process. The order, positioning, sequence and interdependence of the activities provide the structure of the set of activities. Business process activities enable a capability to convert process inputs and resources to an output, acceptable to the customer. Aguilar-Saven (2004) defines business process as "the combination of a set of activities within an enterprise with a structure describing their logical order and dependence whose objective is to produce a desired result". Laakso (1997) describes the business process as "a structured, measured set of activities and flows that use necessary resources of the organization to provide specified output for a particular customer ". Antilla and Jussila (2013) define a process as productive activity, which include working for something, moving of people, materials and information, and interacting. Activities they define as elementary processes which make up the processes, and people are considered as most important resources and actors in business processes (Antilla and Jussila, 2013, p. 920). Similarly, Davenport (1993), Hammer and Champy (1993) suggest the main elements of the business process - activities positioned at the time and place with the definite determination of the beginning and an end, also elements of process' input and an output that is of value to a customer. Exploring the concept of business process, Bekgaard (2009) generalizes that process activities include "movement, manipulation, consumption of materials and information, and coordination, control and evaluation of work tasks performed by the actors - employees or customers". Bekgaard (2009) introduces event - based process ontology. It represents the process as the set of events, which have participants, objects, descriptive properties, information and consequences for business operations and processes state.

Business process is described by the set of its properties. Quantification of the process properties enable to measure the process. As Cardoso (2008) defined, "business process measurement is the task of empirically and objectively assigning numbers to the properties of business processes in such a way so as to describe them"

Operation of the business process activities is determined by the process attributes of variety and complexity (Antilla and Jussila, 2013), as Antilla and Jussila (2013) noted, there were three types of variety modes of process activities - mechanistic, organic, dynamic. Cardoso (2008) define process complexity as "the degree to which a process is difficult to analyze, understand, or explain. It may be characterized by the number and intricacy of activity interfaces, transitions, conditional and parallel branches, the existence of loops, roles, activity categories, the types of data structures, and other process characteristics" (Cardoso, 2008, p.53). Cardoso (2008) also defined other process properties - cost, maintainability, and reliability.

Business organizations are the systems of processes and structures. According to their functionalities, processes are associated to the particular domains, as of the domain, there are market processes, customer processes, management processes, support processes (Antilla and Jussila, 2013). Dervitsiotis (1999) distinguishes basic processes (which deliver product to external customer), support processes (which deliver materials and information to internal customers) and core or critical processes (which affect critical success factors of business organization).

Description and design of the process is generally qualified in process modeling approach. Process model includes process activities, agents (actors), roles, artifacts (Curtis et al., 1992). Curtis et al. (1992) explored the 
The International Journal

ENTREPRENEURSHIP AND SUSTAINABILITY ISSUES

ISSN 2345-0282 (online) http://jssidoi.org/jesi/

2018 Volume 6 Number 1 (September)

http://doi.org/10.9770/jesi.2018.6.1(15)

process model elements by functional, behavior, organizational, informational perspectives. Authors attach activities and flows of artifacts, data and products to the functional activity. Sequencing of activities, feedback loops, activity iteration authors relate to behavior perspective. Process agents, physical media and appliances used for transfer of entities were attached to organizational perspective. Informational entities of data, artifacts, products, objects are represented by informational perspective. Process structure is complex, therefore diagnostic of the process attributes, effects and results require the examination from various perspectives.

\section{Analysis of business process improvement and effects}

An analysis of business processes covers a variety of approaches to improving business processes. Business process reengineering, business process redesign, business process management, provide the knowledge about the methods, tools and techniques, which enable process transformation, and also address the principles and methods for evaluation of the effects, associated to business process transformation. Business process analysis enables to identify process problems, to develop process changes and to evaluate the effect of process redesign. Business process analysis is equally important due to the consistency of process performance and organizations performance. Existing literature provide a holistic approach to business process analysis, which supports the idea that the goal of development of business performance can be achieved through improved processes. Given this approach, the task of developing optimal business process can't be solved improving and optimizing single process in the system of organizational processes. A broad overview of the literature on the impact of process orientation is provided by Kohlbacher (2010). This author summarizes that positive effect of organizations" process orientation on business performance is predominant finding in the studies. Also the effects of customer satisfaction increase, quality improvement, cost reduction, financial performance improvement are identified (Kohlbacher 2010, p.135).

Due to the importance of process analysis for the process development as well as business development, there is still a need for further research on process analysis methods and concepts. However, Davamanirajan et al. notices, "process level analysis is still in its infancy" (Davamanirajan, 2006, p.66).

In the literature business process analysis is presented by various approaches, methods and techniques, therefore, identification of the types of analysis, based on the purpose of analysis is useful for perceiving processes and selecting the appropriate method. Notable review and typology regarding business process analysis was provided by Vergidis et al. (2008). The authors have highlighted these types of process analysis: observational analysis, validation, verification, performance analysis and evaluation, and simulation. Mostly analytical methods have been proposed for performance analysis and evaluation.

\section{Method}

A meta-analysis was carried out to analyze the research questions. Structural literature review has been adapted in accordance with the guidelines for systematic literature reviews provided by Boellt and Cecez-Kecmanovic (2015). Topic of the structural literature review was defined as "business process performance analysis", keywords for the systematic search were derived from the research questions.

Literature review was based on a research papers that were available through the EBSCO host, Academic search complete databases. Initial selection criteria for paper to be included in the review were based on the object of the research provided. Business process was selected as the object for the scientific researches. The keywords for the search were constructed as combination of the words: business process, analysis, performance, evaluation. Scientific papers related with the keywords mentioned above were selected for the literature review. Full text 
papers written in English and published in the journals that apply peer review were included for literature analysis.

\section{Results and discussion}

After the search the initial sample has reached 677 papers. The papers for the content analysis were selected after more detailed analysis of abstracts and body of the text. 62 full text papers were considered for content analysis. Content analysis of identified articles provided the evidence and support in extracting the knowledge relevant to answer research questions.

The papers were analysed on the basis of the method and purpose of research, main findings and techniques. Considering the research questions, papers were categorized in two groups. Articles in the first group consider issues relevant to business process attributes and elements, whilst papers of the second group - business process analysis (Appendix 1, Appendix 2, Appendix 3). Six papers cover the both topics (Dervitsiotis, 1999, Corradini et al., 2015, Hadasch et al., 2016, Bergener et al., 2015, Torres, Sidorova, 2015, Solaimani, Bouwman, 2012).

In regard to first research question, contributions of the authors in exploring the characteristics of business process were examined. Knowledge of business process properties is relevant to increasing the effectiveness of business and process management activities, as well as substantiating business strategic decisions.

Categorization of processes (highlighting the most important ones) is relevant for justifying business enterprise management decisions, strategic business decisions and process outsourcing solutions. Research of business process categorization methods in this regard is relevant in solving business administration problems. The identification of key, critical, strategic processes is based on setting process performance criteria and their link with the company's strategic goals and success factors. The authors propose different methods to distinguish the underlying processes. Dervitsiotis (1999) describes critical or core processes in terms of process contribution in achieving strategic goals. An author identified typical process performance criteria and the method to identify critical process by its weighted contribution to strategic goals. Quesada, Gazo (2007) further developed the research on core, key or critical business processes by providing the methodology designed to define critical internal processes in terms of their strength of relationship with the critical success factors. Also Climent et al. (2009) defined critical processes in bank setting, and Hanafizadeh et al. (2009) provided methodology for selecting strategic processes in the investment company.

The improvement of the business enterprise process system is supported by knowledge of the specific processes that improve the overall performance of the system. Specific processes for specific activities, that enable efficiency of the whole process' system, are explored in the papers. Justification for regulative processes, also value creation activities of the process and activities associated to abuse prevention are provided by Regev et al. (2005). Characteristics of collaborative processes and generic collaborative business process modeling framework is investigated by Bouchbout et al. (2012). Process of reviewing performance is developed by Najmi (2005). Supplier integration and high level business process to govern supplier integration within new product development is investigated by Cadden, Downes (2013).

Process identification is relevant to the development and improvement of business processes. Process design solutions in a business enterprise are formed by distinguishing the process properties associated with the desired and undesirable process performance results. Also process eligibility criteria are required to formulate business decisions related to enterprise processes. In this regard are actual criteria of correctness of business process, based on formal verification of the process, explored by Corradini et al. (2015). Other authors provide a solution and 
The International Journal

ENTREPRENEURSHIP AND SUSTAINABILITY ISSUES

ISSN 2345-0282 (online) http://jssidoi.org/jesi/

2018 Volume 6 Number 1 (September)

http://doi.org/10.9770/jesi.2018.6.1(15)

method for enabling another important business process feature - the user's compliance with the process. Process tool of directive explanations, designed to enable user's process compliance, was analysed and evaluated by Hadasch et al. (2016). Undesirable process performance results are associated to process uncertainty, complexity, weakness. Literature provide an analysis of these process properties. Cardoso (2008) explores the complexity characteristic of business process, investigating the concept of complexity and providing the metric to assess the control-flow complexity of business process. Uncertainty characteristic of business processes and measure to assess uncertainty in new processes was investigated by Helquist et al. (2012). Bergener et al. (2015) investigate process weakness, identifying pattern-based approach to detect process weakness automatically. Innovative approach of event based concept of process, defining the process as the set of events rather than the set of activities, was introduced by Bekgaard (2009).

The knowledge of impact and application of business process elements are of value in increasing the business process capacity. Process elements such as configuration characteristics, process capital, components of interorganizational and intra-organizational interaction have significant impact on process results. One of the problems in operationalization of the process elements, such as the process capital, is the measurement issue. Considerable contribution in exploring business process capital is provided by Shang, $\mathrm{Wu}$ (2013). Authors suggested indicator consisting of measures of value of process capital input and output, and capability to manage process. As the employee motivation is desirable assumption of process management, one of the tasks of the business process administration is to motivate employees by introducing effective motivation tools in the organization. In this regard the findings provided in the survey of Torres, Sidorova (2015) are relevant. Results of their survey confirm the effect of work settings on employee, highlighting the mode how process configuration characteristics impact process participants' motivation. Business process researchers provide measures to address the practical issues in the formation of business decisions related to the business process alignment within business model. Solaimani, Bouwman (2012) identified generic components of inter-organizational and intra-organizational interaction and provided conceptual framework for business process alignment within business model.

It can be summarized that the recent studies of business process features and elements explore the process designed for specific functional purposes rather than the general purpose of achieving organizations goals (collaborative, regulative processes). Deployment of the functional processes creates benefits in terms of the knowledge on functional process design and operation. It is noteworthy also, that a generalized analysis that highlights the trend of research in terms of the characteristics and elements of the process is not possible due to insufficient data compatibility.

\begin{tabular}{|c|c|c|c|}
\hline $\begin{array}{l}\text { The main business value } \\
\text { obtained through } \\
\text { research results } \\
\text { (application areas) }\end{array}$ & \multicolumn{2}{|c|}{ Business process elements and properties } & Reference \\
\hline \multirow{2}{*}{$\begin{array}{lr}\text { Justifying } & \text { enterprises' } \\
\text { management } & \text { decisions, } \\
\text { strategic } & \text { decisions, } \\
\text { process } & \text { outsourcing } \\
\end{array}$} & $\begin{array}{l}\text { Business process } \\
\text { according to process purpose: }\end{array}$ & & \\
\hline & $\begin{array}{l}\text { Process types by process } \\
\text { performance link with company's } \\
\text { strategic goals }\end{array}$ & $\begin{array}{l}\text { critical or core processes, critical internal } \\
\text { processes }\end{array}$ & $\begin{array}{l}\text { Dervitsiotis (1999) } \\
\text { Quesada, Gazo (2007), } \\
\text { Climent et al. (2009) }\end{array}$ \\
\hline
\end{tabular}


The International Journal

ENTREPRENEURSHIP AND SUSTAINABILITY ISSUES

ISSN 2345-0282 (online) http://jssidoi.org/jesi/ 2018 Volume 6 Number 1 (September) http://doi.org/10.9770/jesi.2018.6.1(15)

\begin{tabular}{|c|c|c|c|}
\hline solutions & & strategic processes & Hanafizadeh et al. (2009) \\
\hline \multirow{4}{*}{$\begin{array}{l}\text { Improvement of the } \\
\text { business } \\
\begin{array}{l}\text { process system } \\
\text { enterprise }\end{array}\end{array}$} & \multirow{4}{*}{$\begin{array}{l}\text { Process types by specific activity } \\
\text { that enable efficiency of the } \\
\text { system }\end{array}$} & regulative processes & Regev et al. (2005) \\
\hline & & collaborative processes & Bouchbout et al. (2012) \\
\hline & & process of reviewing performance & Najmi (2005) \\
\hline & & $\begin{array}{l}\text { high level business process of supplier } \\
\text { integration }\end{array}$ & Cadden, Downes (2013) \\
\hline \multirow[t]{5}{*}{ Process design solutions } & \multirow[t]{5}{*}{ Business process properties } & correctness of business process & Corradini et al. (2015) \\
\hline & & users' process compliance & Hadasch et al. (2016) \\
\hline & & $\begin{array}{l}\text { uncertainty characteristic of business } \\
\text { processes }\end{array}$ & Helquist et al. (2012) \\
\hline & & process weakness & Bergener et al. (2015) \\
\hline & & complexity & Cardoso (2008) \\
\hline \multirow{4}{*}{$\begin{array}{l}\text { Process capacity } \\
\text { building solutions }\end{array}$} & \multirow[t]{4}{*}{ Business process elements } & process configuration characteristics & Torres, Sidorova (2015) \\
\hline & & $\begin{array}{l}\text { event based concept of process } \\
\text { (conceptual approach to the structure and } \\
\text { functioning of the process) }\end{array}$ & Bekgaard (2009) \\
\hline & & process capital & Shang, Wu (2013) \\
\hline & & $\begin{array}{l}\text { generic components of inter- } \\
\text { organizational and intra-organizational } \\
\text { interaction }\end{array}$ & $\begin{array}{l}\text { Solaimani, } \quad \text { Bouwman } \\
\text { (2012) }\end{array}$ \\
\hline
\end{tabular}

The main research questions considered in the research on business process elements and properties are summarized in table 1. Research frameworks, methods and techniques for investigation of process properties are summarized in Appendix 2.

Table 1. The main research questions considered in the research on business process elements and properties (The list of sampled papers $\mathrm{N}=17$ )

Source: developed by authors

In regard to second research question, main contributions of the authors in exploring the business process analysis are examined. Studies on business process analysis are focused on understanding the effects of process performance on the business performance. It responds to the needs of the business enterprise to properly construct and control business processes by applying appropriate tools for process design and appropriate systems for the evaluation of business process' operation and enterprise performance. Taking into account the value of research findings for various activities and functions of the business enterprise, the following areas are distinguished:

i) connection between the performance of the process and the performance of the business - summarizing studies, the results of which are of value for process and business evaluation and control;

ii) improvement of process performance impact on business performance - summarizing studies, the results of which are of value for business process modeling and development;

iii) business process performance measurement - summarizing studies, the results of which are of value for process evaluation and control;

iv) business process as a part of value chain - summarizing studies, the results of which are of value for the development of business systems.

Connection between the performance of the process and the performance of the business.

The authors choose different perspectives for the analysis. Some of them consider exploring the effect by selecting appropriate indicators of process performance and business level performance and evaluating the 
The International Journal

ENTREPRENEURSHIP AND SUSTAINABILITY ISSUES

ISSN 2345-0282 (online) http://jssidoi.org/jesi/

2018 Volume 6 Number 1 (September)

http://doi.org/10.9770/jesi.2018.6.1(15)

relationship between the performance parameters variation. Hachicha et al. (2016) proposes ontological model for the assessment and analysis of collaborative processes by considering the consolidation of business level performance (based on key performance indicators) and process performance (based on technical indicators). That approach reflects two basic assumptions. The first is that the results of the process affect the results of the business, and secondly, the process evaluation and analysis concepts, methods and tools must be determined in such a way as to cover the causal factors, that is, the results and parameters of the operation of the process, and the consequences factors, that is, performance and parameters of business operation.

Different perspectives of the process performance analysis consider a holistic approach to the organization. Based on this point of view, processes are not only an integral part of a business organization, but processes are considered as antecedents of specific way by which the business enterprise operates. This specific business operation mode is characterized by property of business organization's process orientation. Consequently, focus on the effects of process performance on the business performance capture business organization's process orientation parameters instead of process performance parameters. As a whole, this exploratory approach is expressed in the research of Kohlbacher (2010), Kohlbacher and Gruenwald (2011). Kohlbacher (2010) provided an overview of studies that analyze the impact of process orientation on the results of a business enterprise. The author concludes that positive effects are prevalent in all studies. Kohlbacher and Gruenwald (2011) provided a multidimensional construct of process orientation designed to measure process orientation of the business enterprise.

\section{Improvement of process performance impact on business performance}

Studies on business process performance analysis are focused on exploring the methods and tools that enable to evaluate and enhance the impact of process improvement on the performance of the organization. Consistent with the view that the goal of the process analysis is to improve the process by improving the process's impact on the possibility to attain the goals of the organization, the results of the research highlight the analytical tools designed to enhance the impact of the process on business outcomes.

The methods of enhancement of process impacts presented in the articles are based on the principle of process selection (Darmani and Hanafizadeh, 2013; Lee et al., 2005), the assessment of the company's ability to improve the process (Nichlods, Mo, 2016), the identification of the coherence of the process results with the business results (McCormack, Rauseo, 2005; Franceschini et al., 2013; Dervitsiotis, 1999; Espino-Rodriguez, RodriguezDiaz, 2014; Valiris, Glykas, 2004). Darmani and Hanafizadeh (2013) propose process selection methodology designed to increase probability of business process reengineering success. Lee et al. (2005) present a method for evaluation of business process alternatives, based on the analysis of expected impact of the process on the stated goals of performance. Nichlods and Mo (2016) present a model quantifying the relationship between the enterprise's capability to process improvement and post-improvement performance. McCormack and Rauseo (2005) explore high-level business process map of the enterprise that can be used as a mean of aligning business strategy to process strategy and design. Franceschini et al. (2013) propose a methodology for the evaluation of the impact of performance measurement system on the specific areas of an organization. Dervitsiotis (1999) explore the method (based on Riggs matrix) for evaluation of business process value adding contributions to attain organization's strategic goals. Espino-Rodriguez and Rodriguez-Diaz (2014) develop a methodology to identify operations of the order fulfillment process, related to core competences of an organization. Valiris and Glykas (2004) explored the agent relationship morphism analysis (ARMA) techniques for business process redesign aimed to improve the effectiveness of business processes and operations.

A lot of research aimed at revealing ways to improve the process from the point of view of performance and outcomes. Studies on business process performance analysis are focused on improvement of process design 


\section{The International Journal}

ENTREPRENEURSHIP AND SUSTAINABILITY ISSUES

ISSN 2345-0282 (online) http://jssidoi.org/jesi/

2018 Volume 6 Number 1 (September)

http://doi.org/10.9770/jesi.2018.6.1(15)

(Andersson et al., 2005; Yu et al., 2016; Bosch-Mauchand et al., 2013; Anastassiu et al., 2016; Bolsinger et al., 2015; Torres, Sidorova, 2015; Bisogno et al., 2016; Zhu et al., 2014; Samaranayake et al., 2015; Coskun et al., 2008), IT impact on process performance (Davamanirajan et al., 2006; Hadasch et al., 2016; Abu Rub, Issa, 2012), improvement of the tools for process modeling (Bocciarelli, D’Ambrogio, 2014; De Padua et al., 2014; Li et al., 2004; Corradini et al., 2015; Bergener et al., 2015; Samaranayake, 2009; Vergidis et al., 2008; Helquist, 2009; Wynn et al., 2009; Vom Brocke et al., 2010), evaluation and improvement of process quality (Nestic et al., 2015).

Andersson et al. (2005) propose using process patterns for business process reengineering and defined the stateflow modeling technique as a suitable mean for process pattern foundation. On the basis of an electronic group sales process case, Yu et al. (2016) present an experimental approach to evaluate process model design combining the principles of process design and experimental economics. Bosch-Mauchand et al. (2013) present a method designed to assess product development and production engineering processes in terms of performance and value, based on the principles of value chain and on the methods of knowledge management. Anastassiu et al. (2016) introduce a semi-structured procedural guide for the analysis of ontological transactions and for the identification of process contextual information relevant to the process objectives. Bolsinger et al. (2015) propose a decision model designed to provide a guidance for process improvement determining the parameters that maximizes the value contribution of the process. Torres and Sidorova (2015) provide the survey aimed to assess the impact of business process configuration on the motivation of process participants. Bisogno et al. (2016) explore a method designed to facilitate the analysis of the operational performance of business process and to test for potential process improvements. Zhu et al. (2014) introduce location-awareness in business process management research and explored pattern-based approach aimed to identify location-dependency in process models. Samaranayake et al. (2015) propose a framework of process modeling in hospital settings that covers associated processes, data and patient flow. Coskun et al. (2008) define model aimed to determine process weak points and to distinguish process improvement strategy considering improvement costs.

Davamanirajan et al. (2006) define a process performance model to quantify IT impact on process performance improvement and economic performance model designed to assess process performance effects on the enterprise performance. Hadasch et al. (2016) develop the concept of directive explanations - context dependent feedback to business process users aimed to influence user's process compliance. Abu Rub and Issa (2012) propose role activity diagramming technique aimed to model complex processes in the software industry sector. Bocciarelli, D'Ambrogio (2014) introduce Performability enabled Business Process Modeling Notation to enable prediction of automated business process behavior in terms of performance and reliability. Nestic et al. (2015) propose a fuzzy model for evaluation and improvement of process quality and presented a solution for quality assessment of purchasing process. De Padua et al. (2014) provide comparative study of the results from the applying business process modeling and root cause analysis techniques for the diagnostic of information technology management process. Li et al. (2004) provide framework for modeling and analyzing process workflow, based on a multidimension workflow net and the organization and resource information. Corradini et al. (2015) introduce formal process verification in public administration domain, based on formal verification technique using Petri Net notation. Bergener et al. (2015) explore pattern based process weakness detection approach designed to automatically detect process weakness in semantic process models. Samaranayake (2009) proposes a framework of process integration, automation and optimization in terms of functional applications, business workflows, and additional functionalities. Vergidis et al. (2008) provide a review of the literature on the process modeling techniques highlighting process analysis and optimization capabilities. Helquist (2009) presents a virtual process simulation technique aimed to model process alternatives, considering the geographic and team composition issues. Wynn et al. (2009) explore process verification technique designed to assess the correctness of process with cancellation and OR-joins. Vom Brocke et al. (2010) delineate a framework for process redesign that integrates financial considerations and process modeling. 
The International Journal

ENTREPRENEURSHIP AND SUSTAINABILITY ISSUES

ISSN 2345-0282 (online) http://jssidoi.org/jesi/

2018 Volume 6 Number 1 (September)

http://doi.org/10.9770/jesi.2018.6.1(15)

Some studies explore specific processes - electronic group sales process (Yu et al., 2016), product development and production engineering processes (Bosch-Mauchand et al., 2013), purchasing process (Nestic et al., 2015), information technology management process (De Padua et al., 2014), public administration processes (Corradini et al., 2015), complex processes in software industry (Abu Rub, Issa, 2012), processes in hospital setting (Samaranayake et al., 2015).

\section{Business process performance measurement}

A lot of researches explore ways to evaluate the process. Various process measurement concepts are based on the notion that process measurement is an instrument for managing the process and has an impact on process outputs and business outcomes (Robson, 2004, Jarrar, 2004). Robson (2004) discusses the effect of process performance measurement on the improvement of process and organizational performance. Jarrar (2004) summarizes the importance of performance measurement systems for business management and highlighted the streams of performance measurement development. The scientific literature not only introduces the approaches and methods of process performance evaluation, but also contains works summarizing the process evaluation studies (van Looy, Shafagatova, 2016, Gonzalez et al., 2010). Van Looy, Shafagatova (2016) explored the patterns in the research on business process performance measurement and provided categorized list of process related performance indicators. Gonzalez et al., 2010 carried out systematic review of literature that deals with business process measurement.

The papers present process measurement methods designed for specific purposes - measurement system aimed to consider specific levels of company performance (Khan and Wibisono, 2008), composite measure of the process aimed to measure process in terms of process goals (Yen, 2009), customer oriented process performance measurement system (Wieland et al., 2015), measurement system for corporate sustainability (Padua andJabbour, 2015), measurement of web-enabled processes based on key performance indicators (Pun et al., 2012), process assessment method aimed to assess environmental implications to technological processes (Sarkis et al., 2006), measure designed to enable selection of advantageous production system (Chin and Saman, 2004), performance measurement system aimed to measure internal processes in terms of enabling inter-organizational cooperation (Alfaro et al., 2009), performance measurement from the perspective of supply chain (Morgan, 2004). Khan and Wibisono (2008) propose a knowledge based process performance measurement system for designing and benchmarking of measurement system which considers five levels of company performance and techniques of analytic hierarchy process and gap analysis. Yen (2009) proposes the conceptual model aimed to create composite measure of business process, which consists of single measures relevant to process goals. Wieland et al. (2015) identified the requirements of customer oriented process performance measurement system based on customer demands and critical design features. Padua and Jabbour (2015) provide conceptual model of corporate sustainability performance measurement system considering specific issues relevant to sustainability. Pun et al. (2012) propose a process analysis method aimed to facilitate the analysis of traffic intensive web-enabled business processes in terms of key performance indicators evaluated according to audit trail data, web server logs and stress testing logs. Sarkis et al. (2006) introduce a methodology that involves activity-based costing, analytic hierarchy process and business process modeling techniques, which is intended to assess environmental implications in evaluating alternative technological processes. Chin and Saman (2004) explore a performance measure suitable for the selection of advantageous production system for a company. Alfaro et al. (2009) define the basic characteristics of performance measurement systems aimed to measure internal business processes in the perspective of inter-organizational cooperation. Morgan (2004) highlights the preconditions of effective performance measurement from the supply chain perspective.

\section{Business process as a part of value chain}


The International Journal

ENTREPRENEURSHIP AND SUSTAINABILITY ISSUES

ISSN 2345-0282 (online) http://jssidoi.org/jesi/

2018 Volume 6 Number 1 (September)

http://doi.org/10.9770/jesi.2018.6.1(15)

In some papers processes are analyzed as a part of value chain. Main focuse is on process integration, interorganizational and intra-organization process interaction, process outsourcing issues. Berente et al. (2009) characterize process integration in terms of organizational, data-processing, and application integration and defined principles of process integration. Wu and Park (2009) introduce theoretical framework aimed to facilitate the implementation of process outsourcing decisions. Solaimani and Bouwman (2012) propose a framework aimed to improve the alignment between business model and business process considering the generic, horizontal and vertical inter-organizational and intra-organizational interaction components.

The main research questions considered in the research on business analysis are summarized in the table. Research frameworks, methods and techniques for investigation of process analysis are summarized in Appendix 3.

Table 2. The main research questions considered in the research on business analysis (The list of sampled papers $\mathrm{N}=51$ )

\begin{tabular}{|c|c|}
\hline Business process analysis & Reference \\
\hline $\begin{array}{l}\text { Connection between the performance of the process and } \\
\text { the performance of the business }(\mathrm{N}=3)\end{array}$ & $\begin{array}{l}\text { Hachicha et al., 2016; Kohlbacher, 2010; } \\
\text { Kohlbacher and Gruenwald, } 2011\end{array}$ \\
\hline $\begin{array}{l}\text { Improvement of the process performance impact on } \\
\text { business performance }(\mathrm{N}=8)\end{array}$ & $\begin{array}{l}\text { Darmani, Hanafizadeh, 2013; Nichlods, Mo, 2016; McCormack, } \\
\text { Rauseo, 2005; Franceschini et al., 2013; Dervitsiotis, 1999; Lee et } \\
\text { al., 2005; Espino-Rodriguez, Rodriguez-Diaz, 2014; Valiris, } \\
\text { Glykas, } 2004\end{array}$ \\
\hline $\begin{array}{l}\text { Improvement of the process as a tool intended to } \\
\text { generate performance }(\mathrm{N}=24)\end{array}$ & $\begin{array}{l}\text { Andersson et al., 2005; Yu et al., 2016; Davamanirajan et al., 2006; } \\
\text { Bocciarelli, D'Ambrogio, 2014; Bosch-Mauchand et al., 2013; } \\
\text { Nestic et al., 2015; de Padua et al., 2014; Li et al. 2004; Corradini } \\
\text { et al., 2015; Hadasch et al., 2016; Abu Rub, Issa, 2012; Anastassiu } \\
\text { et al., 2016; Bolsinger et al., 2015; Bergener et al., 2015; } \\
\text { Samaranayake et al., 2015; Torres, Sidorova, 2015; Bisogno et al., } \\
\text { 2016; Vergidis et al., 2008; Zhu et al., 2014; Helquist, 2009; Wynn } \\
\text { et al., 2009; Samaranayake, 2009; Coskun et al., 2008; vom Brocke } \\
\text { et al., 2010 }\end{array}$ \\
\hline Business process performance measurement $(\mathrm{N}=13)$ & $\begin{array}{l}\text { Gonzalez et al., 2010; Khan, Wibisono, 2008; Yen, 2009; Wieland } \\
\text { et al., 2015; Padua et al., 2015; } \\
\text { Pun et al., 2012; Sarkis et al., 2006; Robson, 2004; Jarrar, 2004; } \\
\text { Chin, Saman, 2004; Alfaro et al., 2009; Morgan, 2004; Van Looy, } \\
\text { Shafagatova, 2016 }\end{array}$ \\
\hline Business process as part of value chain $(\mathrm{N}=3)$ & Berente et al., 2009; Wu, Park, 2009; Solaimani, Bouwman, 2012 \\
\hline
\end{tabular}

Source: developed by authors

\section{Framework integrating the domains of business process analysis}

Conceptualization of business process, adopted in the business process analysis research enables to capture the streams of research and also to systematize accumulated knowledge of business process into three levels of analysis - process level, intra-organizational level and intra-organizational level.

Framework integrating the domains and levels of business process analysis summarizes the results of this study (Fig. 1). 


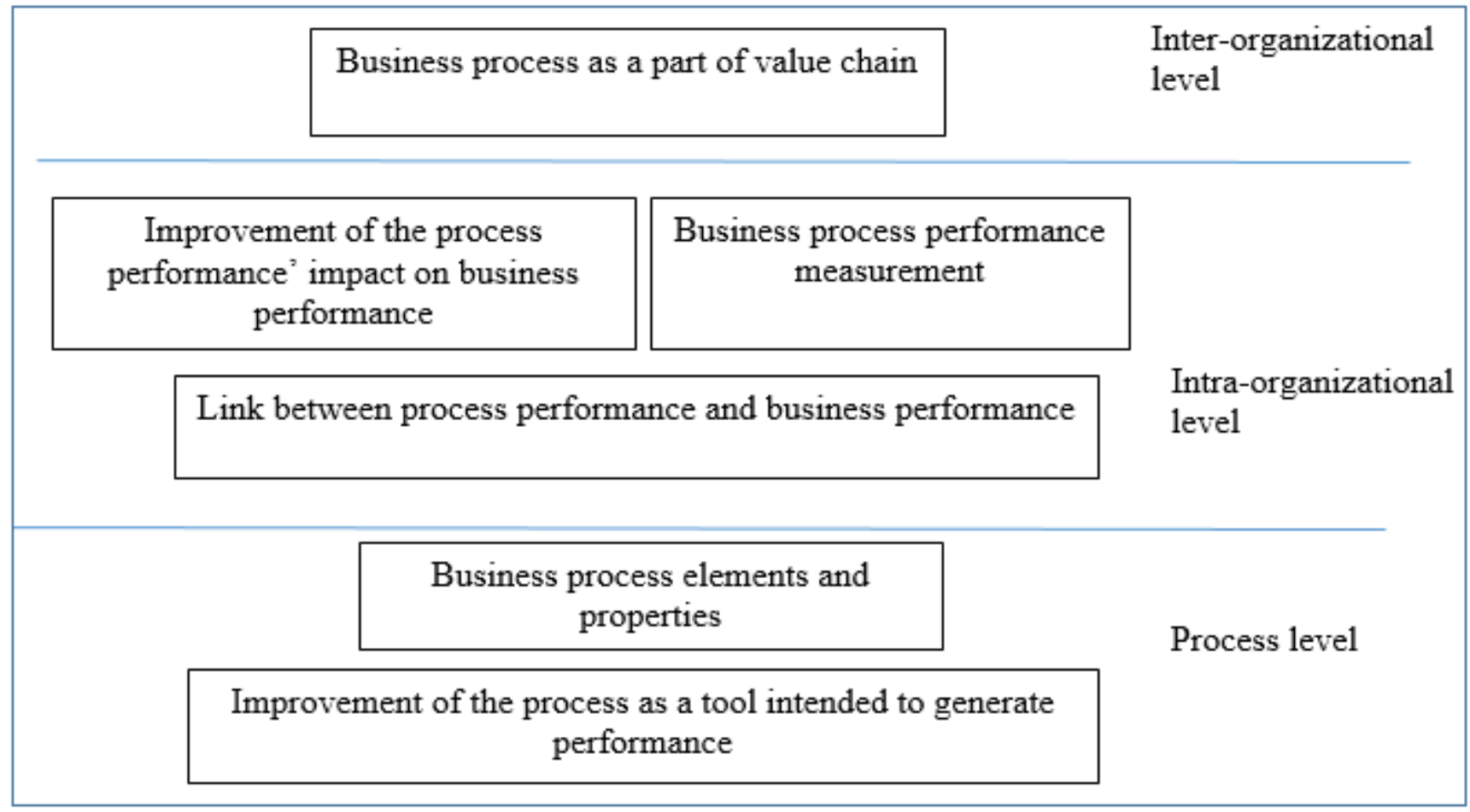

Fig.1. Framework integrating domains and levels of business process analysis Source: developed by authors

After the content analysis of selected papers a few research streams were highlighted:

- Business process as a set of activities within an enterprise, designed to create value to the customer and generate value to organization

- Business process as a system of activities, participants, information, interactions, rules, which is a tool intended to generate performance

- Business process performance measurement

- Business process as a part of value chain.

Generalized process investigation directions distinguished in relation to the first research question: conceptual approach to the structure and functioning of the processes, business process type according to process purpose, business process properties, business process elements $(\mathrm{N}=17)$.

Papers of the process level of analysis group anticipate business process as a tool designed to generate performance providing an output. Business process research is focused on finding the characteristics of a process that enable the achievement of process operational goal in most efficient way. Characteristics of process correctness, process user's compliance are related to the opportunities that enable performance development. However, characteristics of process weakness, complexity, uncertainty are related to threats to fail to achieve the goals of the process. Knowledge of the conditions and assumptions for these features provides opportunities for better management of processes.

Generalized process investigation direction distinguished in relation to the second research question: Improvement of the process as a tool intended to generate performance $(\mathrm{N}=24)$. 
Generalized process investigation directions were distinguished:

- Relationship between performance of the process and the performance of the business $(\mathrm{N}=3)$

- Improvement of the process performance impact on business performance $(\mathrm{N}=8)$

- Business process performance measurement $(\mathrm{N}=13)$

Relationship between performance of the process and the performance of the business

Papers of the intra-organizational level of analysis group are based on the view that the preconditions for improving the process relate to the process features enabling to achieve the goals of the organization in the optimal way. Options and prerequisites to improve the process are discovered by linking the characteristics of the process or process design with the measures of organizations' goals. This mode of research postulates the idea that there is direct connection between operation of the process and operation of the business. Therefore, improvement of the process performance leads to business performance improvement.

\section{Improvement of the process performance impact on business performance}

The assumptions for improving the process are determined by detailed analysis of the process's structure and performance in relation to the objectives of the process. Process model design and performance is the main focus in these studies. Recent research in this research stream emphasizes the problem of the process as a dynamic system capable of generating changes in the response to environmental factors, as well as enabling automatic operation of the process.

\section{Business process performance measurement}

Papers of the intra-organizational level of analysis group also focus on the issues of business process performance measurement. This mode of research postulate the ideas that the proper measurement system can influence the operation of the process; the framework for the measurement of process performance must be consistent with the objectives of the process and organization and in that way it will generate the impact on business outcomes, suitable indicators and metrics to measure business process performance should be consistent with process and business goals.

Generalized process investigation direction was distinguished in relation to the second research question: Business process as part of value chain $(\mathrm{N}=3)$.

Papers of the inter-organizational level of analysis group of process studies explore the concept of business process alignment within the product value chain, emphasizing the business process interactions in the interorganizational mode. Also outsourcing is the object of research that analyzes methods to facilitate process outsourcing decision-making.

\section{Exploratory potential areas for future inquiry}

Process analysis is continuous activity of process management as business enterprise continuously adapt to dynamic environment in which it operates. Measures, metrics for business process performance and techniques for business process data gathering and monitoring are known (Van Looy, Shafagatova, 2016; Vergidis et al., 2008; Gonzalez et al., 2010). Also some papers provide the analysis of environmental implications to the technological processes and process performance measurement from the supply chain perspective ( Sarkis et al., 2006; Morgan, 2004). However, proper evaluation of business processes need complex data on business 
The International Journal

ENTREPRENEURSHIP AND SUSTAINABILITY ISSUES

ISSN 2345-0282 (online) http://jssidoi.org/jesi/

2018 Volume 6 Number 1 (September)

http://doi.org/10.9770/jesi.2018.6.1(15)

operations's context or environment, such as customer needs and satisfaction, organization competitiveness, data of resource markets, environmental implications on process performance. Business operation's environment data are supplied by the means of transactions and communication with customers, suppliers, stakeholders, competitors. From the point of view of process analysis these channels of information usually are not created in consistent mannier (data, data requirements lack of consistency), therefore, it is limited availability of data integration, tracking, monitoring and forecast the effects of various factors of environment on business operations. Future research on business process analysis should be directed towards the search of systems, procedures and techniques designed to ensure and manage the flow of external information and to integrate this information in the business process management systems. As the potential area of future enquiry, the integration of external and internal information is significant due to its support to the improvement of the process and business performance, based on more comprehensive knowledge of the consumers' and other stakeholders' needs.

Business process design and reengineering projects' implementation do not always successfully provide the projected results and always it is a risk that the project will fail or that sufficient performance will not be achieved. Analysis of the literature provides some insight of the limitation in deeper analysis for the risk management processes ( 1 table). Due to the complexity of the process systems and diversity of the risk effects and risk factors, the risk management process modeling should ensure the integration of activities for the management of a-priori risk and emergent risk factors.

Development of complex production processes, innovative business practices and the growing experience of the participants of the process create prerequisites for the implementation of intensive knowledge-based operating processes. These intensive knowledge-based processes are different from the production processes. The most significant difference is in the nature of the interaction between the participants involved in the process and the process systems. Knowledge-based processes require implementing flexible interactions and high variability workflow design; however, this type of interaction is not profoundly studied.

An approach to integrate the customer into the product lifecycle processes is considered relevant. Although, customer involvement in product design and development processes is related to the problem of user engagement and manufacturer control uncertainty. The modes of customer involvement in the process, effective control of customer actions and efficient management of overall process with the customer are of interest for future research. Customer participation in business processes is also relevant in service settings. Although, business process development in service industries provided some knowledge on the enablers of high customer value, development of efficiently operating models of the process of interaction between enterprise and its customers is not deeply investigated.

\section{Conclusions}

Structured analysis of scientific literature revealed the levels of research of business processes and the main directions of research. Conceptualization of research on business process analysis issues enable to capture three levels of analysis - process level, intra-organizational level and intra-organizational level. The main trends of business process analysis research at the process level is related to the search for knowledge that enables business theorists and practitioners to know the process properties, elements and types, as well as to improve the process as a tool intended to generate performance. The main streams of research at the intra-organizational level capture the issues of the relationship between performance of the process and performance of the business, business process performance measurement and improvement of the process performance impact on business performance. Studies emphasizing process analysis at the inter-organizational level focus on process alignment within the product value chain and process interactions in the inter-organizational mode. 
The International Journal

ENTREPRENEURSHIP AND SUSTAINABILITY ISSUES

ISSN 2345-0282 (online) http://jssidoi.org/jesi/

2018 Volume 6 Number 1 (September)

http://doi.org/10.9770/jesi.2018.6.1(15)

Structured literature review has enabled to distinguish the relevant but less investigated issues of business process performance and to identify exploratory potential areas for future inquiry. The importance of these studies is emphasized: external information management processes and the integration of external information into process management, development and management of specific processes such as risk, knowledge creation and knowledge based processes, user involvement in business processes.

\section{References}

Aguilar-Saven R.S. 2004. Business process modelling: Review and framework, International Journal of Production Economics. 90: 129149. http://dx.doi/10.1016/S0925-5273(03)00102-6

Anttila, J.; Jussila, K. 2013. An advanced insight into managing business processes in practice, Total Quality Management 24(8): 918-932. Retrieved from http://dx.doi/10.1080/14783363.2013.791105

Boellt, S.K.; Cecez-Kecmanovic, D. 2015. On being 'systematic' in literature reviews in IS, Journal of Information Technology 30:161173. http://dx.doi/10.1057/jit.2014.26

Curtis, B.; Kellner, M.I.; Over J. 1992. Process modeling, Communications of the ACM September 35(9): 75-90. Retrieved from https://doi.org/10.1145/130994.130998

Davenport, T.H.; Short J.E. 1990. The new industrial engineering: information technology and business process redesign, Sloan Management Review 31 (4): 11-27.

Davenport, T.H. 1993. Process Innovation: Re-engineering Work through Information Technology. Boston, MA: Harvard Business School Press.

Dumas, M.; La Rosa, M.; Mendling, J.; Reijers, H.A. 2013. Fundamentals of Business Process Management. Heidelberg: Springer. http://dx.doi/10.1007/978-3-642-33143-5

Hammer, M.; Champy, J. 1993. Reengineering the Corporation: A Manifesto for Business Revolution. New York: Harper Business.

Irani, Z.; Hlupic, V.; Giaglis, G.M. 2002. Business process reengineering: An analysis perspective, International Journal of Flexible Manufacturing Systems 14: pp. 5-10. Retrieved from https://doi.org/10.1023/A:1013868430717

Khosravi, A. 2016. Business process rearrangement and renaming: A new approach to process orientation and improvement, Business Process Management Journal 22(1): 116-139. Retrieved from https://doi.org/10.1108/BPMJ-02-2015-0012

Laakso, T. 1997. Process Assessment Method - an approach for business process development. In: Plonka F., Olling G. (eds) Computer Applications in Production and Engineering. IFIP — The International Federation for Information Processing. Boston, MA: Springer. Retrieved from https://doi.org/10.1007/978-0-387-35291-6_21

Van der Aalst, W.M.P. (2004). Business process management: a personal view, Business Process Management Journal 10(2), Retrieved from https://doi.org/10.1108/bpmj.2004.15710baa.001 
Appendix 1.

The list of sampled papers $(\mathrm{N}=62)$

1. Abu Rub, F. A.; Issa, A.A. 2012. A business process modeling-based approach to investigate complex processes: Software development case study, Business Process Management Journal 18(1): 122-137. Retrieved from https://doi.org/10.1108/14637151211215046

2. Alfaro, J. J.; Rodriguez-Rodriguez, R.; Verdecho, M.J.; Ortiz, A. 2009. Business process interoperability and collaborative performance measurement, International Journal of Computer Integrated Manufacturing 22(9): 77-889. Retrieved from http://dx.doi.org/10.1080/09511920902866112

3. Anastassiu, M.; Santoro, F. M.; Recker, J.; Rosemann, M. 2016. The quest for organizational flexibility: Driving changes in business processes through the identification of relevant context, Business Process Management Journal 22(4): 763-790, Retrieved from https://doi.org/10.1108/BPMJ-01-2015-0007

4. Andersson, B.; Bider, I.; Johannesson, P.; Perjons, E. 2005. Towards a formal definition of goaloriented business process patterns, Business Process Management Journal 11(6): 650-662. Retrieved from https://doi.org/10.1108/14637150510630846

5. Bækgaard, L. 2009. Event-based conceptual modeling, Business Process Management Journal 15(4): 469-486. Retrieved from https://doi.org/10.1108/14637150910975499

6. Berente, N.; Vandenbosch, B.; Aubert, B. 2009. Information flows and business process integration, Business Process Management Journal 15(1): 119-141. Retrieved from https://doi.org/10.1108/14637150910931505

7. Bergener, P.; Delfmann, P.; Weiss, B.; Winkelmann, A. 2015. Detecting potential weaknesses in business processes: An exploration of semantic pattern matching in process models, Business Process Management Journal 21(1): 25-54. Retrieved from https://doi.org/10.1108/BPMJ-07-2013-0103

8. Bisogno, S.; Calabrese, A.; Gastaldi, M.; Levialdi Ghiron, N. 2016. Combining modelling and simulation approaches: How to measure performance of business processes, Business Process Management Journal 22(1): 56-74. Retrieved from https://doi.org/10.1108/BPMJ-02$\underline{2015-0021}$

9. Bocciarelli, P.; D‘Ambrogio, A. 2014. A model-driven method for enacting the design-time QoS analysis of business processes, Software System Model Journal 13: 573-598. http://dx.doi/10.1007/s10270-013-0345-5

10. Bolsinger, M.; Elsäßer, A.; Helm, C.; Röglinger, M. 2015. Process improvement through economically driven routing of instances, Business Process Management Journal 21(2): 353-378. Retrieved from https://doi.org/10.1108/BPMJ-02-2014-0011

11. Bosch-Mauchand, M.; Belkadi, F.; Bricogne, M.; Eynard, B. 2013. Knowledge-based assessment of manufacturing process performance: integration of product lifecycle management and value-chain simulation approaches, International Journal of Computer Integrated Manufacturing 26(5): 453-473. Retrieved from http://dx.doi.org/10.1080/0951192X.2012.731611

12. Bouchbout, K.; Akoka, J.; Alimazighi, Z. 2012. An MDA-based framework for collaborative business process modelling, Business Process Management Journal 18(6): 919-948. Retrieved from https://doi.org/10.1108/14637151211283357

13. Cadden, T.; Downes, S.J. 2013. Developing a business process for product development, Business Process Management Journal 19(4): 715-736. Retrieved from https://doi.org/10.1108/BPMJJan-2012-0006

14. Cardoso, J. 2008. Business Process Control-Flow Complexity: Metric, Evaluation, and Validation, International Journal of Web Services Research 5(2): 49-76.

15. Chin, H. G.; Zameri Mat Saman, M. 2004. Proposed analysis of performance measurement for a production system, Business Process Management Journal 10(5): 570-583. Retrieved from https://doi.org/10.1108/14637150410559234

16. Climent, C.; Mula, J.; Hernández, J.E. 2009. Improving the business processes of a bank, Business Process Management Journal 15(2): 201-224. Retrieved from https://doi.org/10.1108/14637150910949452

17. Corradini, F.; Polini, A.; Re, B. 2015. Inter-organizational business process verification in public administration, Business Process Management Journal 21(5): 1040-1065. Retrieved from https://doi.org/10.1108/BPMJ-02-2014-0013 
18. Coskun, S.; Basligil, H.; Baracli, H. 2008. A weakness determination and analysis model for business process improvement, Business Process Management Journal 14(2): 243-261. Retrieved from https://doi.org/10.1108/14637150810864961

19. Dallavalle de Pádua, S.I.; Chiappetta Jabbour, C.J. 2015. Promotion and evolution of sustainability performance measurement systems from a perspective of business process management: From a literature review to a pentagonal proposal, Business Process Management Journal 21(2): 403-418. Retrieved from https://doi.org/10.1108/BPMJ-10-2013-0139

20. Dallavalle de Pádua, S.I.; Hornos da Costa, J.M.; Segatto, M.; Aparecido de Souza Júnior, M.; Chiappetta Jabbour, C.J. 2014. BPM for change management: two process diagnosis techniques, Business Process Management Journal 20(2): 247-271. Retrieved from https://doi.org/10.1108/BPMJ-03-2013-0039

21. Darmani, A.; Hanafizadeh, P. 2013. Business process portfolio selection in re-engineering Projects, Business Process Management Journal 19(6): 892-916. Retrieved from https://doi.org/10.1108/BPMJ-08-2011-0052

22. Davamanijaran, P.; Kaufmann, R. J.; Kriebel, C. H.; Mukhopadghay, T. 2006. Systems Design, Process Performance, and Economic Outcomes in International Banking, Journal of Management Information Systems 23(2): 65-90. Retrieved from https://doi.org/10.2753/MIS0742-1222230204

23. Dervitsiotis, K.N. 1999. How to attain and sustain excellence with performance-based process management, Total quality management 10 (3): 309-326.

24. Espino-Rodríguez, T.F.; Rodríguez-Díaz, M. 2014. Determining the core activities in the order fulfillment process: an empirical application, Business Process Management Journal 20(1): 2-24. Retrieved from https://doi.org/10.1108/BPMJ-01-2013-0012

25. Franceschini, F.; Galetto, M.; Turina, E. 2013. Techniques for impact evaluation of performance measurement systems, International Journal of Quality \& Reliability Management 30(2): 197 - 220. Retrieved from http://dx.doi.org/10.1108/02656711311293599

26. González, L.S.; Rubio, F.G.; González, R.F.; Velthuis, M.P. 2010. Measurement in business processes: a systematic review, Business Process Management Journal 16(1): 114-134. Retrieved from https://doi.org/10.1108/14637151011017976

27. Hachicha, M.; Fahad, M.; Moalla, N.; Ouzrout, Y. 2016. Performance assessment architecture for collaborative business processes in BPM-SOA-based environment, Data \& Knowledge Engineering 105: 73-89. Retrieved from http://dx.doi.org/10.1016/j.datak.2015.12.002

28. Hadasch, F.; Maedche, A.; Gregor, S. 2016. The influence of directive explanations on users' business process compliance performance, Business Process Management Journal 22(3): 458-483. Retrieved from https://doi.org/10.1108/BPMJ-05-2015-0067

29. Hanafizadeh, P.; Rezaei, M.; Ghafouri, A. 2009. Defining strategic processes in investment companies: An exploration study in Iranian Investment Companies, Business Process Management Journal 15(1): 20-33. Retrieved from https://doi.org/10.1108/14637150910931442

30. Helquist, J.H.; Cox, J.J.; Walker, A. 2009. Exploring diverse process and team alternatives through virtual process simulation, Business Process Management Journal 15(5): 633-652. Retrieved from https://doi.org/10.1108/14637150910987883

31. Helquist, J.H.; Deokar, A.; Cox, J.J.; Walker, A. 2012. Analyzing process uncertainty through virtual process simulation, Business Process Management Journal 18(1): 4-19. Retrieved from https://doi.org/10.1108/14637151211214984

32. Jarrar, Y. 2004. Performance measurement in the 21st century: From performance measurement to performance management, Business Process Management Journal 10(5). Retrieved from https://doi.org/10.1108/bpmj.2004.15710eaa.001

33. Khan, M.K.; Wibisono, D. 2008. A hybrid knowledge-based performance measurement system, Business Process Management Journal 14(2): 129-146. Retrieved from https://doi.org/10.1108/14637150810864899

34. Kohlbacher, M. 2010. The effects of process orientation: a literature review, Business Process Management Journal 16(1): 135-152. Retrieved from https://doi.org/10.1108/14637151011017985

35. Kohlbacher, M.; Gruenwald, S. 2011. Process orientation: conceptualization and Measurement, Business Process Management Journal 17(2): 267-283. Retrieved from https://doi.org/10.1108/14637151111122347 
36. Lee, S.M.; Olson, D.L.; Trimi, S.; Rosacker, C.M. 2005. An integrated method to evaluate business process alternatives, Business Process Management Journal 11(2): 198-212. Retrieved from https://doi.org/10.1108/14637150510591183

37. Li, J.; Fan, Y.; Zhou, M. 2004. Performance Modeling and Analysis of Workflow, IEEE Transactions on Systems, Man, And Cybernetics - Part A: Systems and Humans 34(2): 229-242. Retrieved from http://dx.doi.org/0.1109/TSMCA.2003.819490

38. McCormack, K.; Rauseo, N. 2005. Building an enterprise process view using cognitive mapping, Business Process Management Journal 11(1): 63-74. Retrieved from https://doi.org/10.1108/14637150510578737

39. Morgan, C. 2004. Structure, speed and salience: performance measurement in the supply chain, Business Process Management Journal 10(5): 522-536. Retrieved from https://doi.org/10.1108/14637150410559207

40. Najmi, M.; Rigas, J.; Fan, IS. 2005. A framework to review performance measurement systems, Business Process Management Journal 11(2): 109-122. https://doi.org/10.1108/14637150510591129

41. Nestic, S.; Djordjevic, A.; Puskaric, H.; Zahar Djordjevic, M.; Tadic, D.; Stefanovic, M. 2015. The evaluation and improvement of process quality by using the fuzzy sets theory and genetic algorithm approach, Journal of Intelligent \& Fuzzy Systems 29: 2017-2028. Retrieved from http://dx.doi.org/10.3233/IFS-151679

42. Nicholds, B.A.; Mo, J.P.T. 2016. Estimating performance from capabilities in business process improvement, Business Process Management Journal 22(6): 1099-1117. Retrieved from https://doi.org/10.1108/BPMJ-09-2015-0129

43. Pun, K.I.; Si, Y. W.; Pau, K. C. 2012. Key performance indicators for traffic intensive web-enabled business processes, Business Process Management Journal 18(2): 250-283. Retrieved from https://doi.org/10.1108/14637151211225199

44. Quesada, H.; Gazo, R. 2007. Methodology for determining key internal business processes based on critical success factors: A case study in furniture industry, Business Process Management Journal 13(1): 5-20. Retrieved from https://doi.org/10.1108/14637150710721104

45. Regev, G.; Alexander, I.F.; Wegmann, A. 2005. Modelling the regulative role of business processes with use and misuse cases, Business Process Management Journal 11(6): 695-708. Retrieved from https://doi.org/10.1108/14637150510630864

46. Robson, I. 2004. From process measurement to performance improvement, Business Process Management Journal 10(5): 510-521. Retrieved from https://doi.org/10.1108/14637150410559199

47. Samaranayake, P. 2009. Business process integration, automation, and optimization in ERP: Integrated approach using enhanced process models, Business Process Management Journal 15(4): 504-526. Retrieved from https://doi.org/10.1108/14637150910975516

48. Samaranayake, P.; Dadich, A.; Hayes, K. J.; Sloan, T. 2015. Patient-journey modelling and simulation in computed tomography: An integrated framework, Business Process Management Journal 21(5): 988-1014. Retrieved from https://doi.org/10.1108/BPMJ-10-2014$\underline{0097}$

49. Sarkis, J.; Meade, L.; Presley, A. 2006. An activity based management methodology for evaluating business processes for environmental sustainability, Business Process Management Journal 12(6): 751-769. Retrieved from https://doi.org/10.1108/14637150610710918

50. Shang, S.S.C.; Wu, YL. 2013. Measuring process capital from a system model perspective, Business Process Management Journal 19(4): 662-679. Retrieved from https://doi.org/10.1108/BPMJ-11-2012-0117

51. Solaimani, S.; Bouwman, H. 2012. A framework for the alignment of business model and business processes: A generic model for trans-sector innovation, Business Process Management Journal 18(4): 655-679. Retrieved from https://doi.org/10.1108/14637151211253783

52. Torres, R.; Sidorova, A. 2015. The effect of business process configurations on user motivation, Business Process Management Journal 21(3): 541-563. Retrieved from https://doi.org/10.1108/BPMJ-09-2013-0131

53. Valiris, G.; Glykas, M. 2004. Business analysis metrics for business process redesign, Business Process Management Journal 10(4): 445-480. Retrieved from https://doi.org/10.1108/14637150410548100 
The International Journal

ENTREPRENEURSHIP AND SUSTAINABILITY ISSUES

ISSN 2345-0282 (online) http://jssidoi.org/jesi/

2018 Volume 6 Number 1 (September)

http://doi.org/10.9770/jesi.2018.6.1(15)

54. Van Loy, A.; Shafagatova, A. 2016. Business process performance measurement: a structured literature review of indicators, measures and metrics, SpringerPlus (2016) 5:1797. https://doi.org/10.1186/s40064-016-3498-1

55. Vergidis, K.; Tiwari, A.; Majeed, B. 2008. Business Process Analysis and Optimization: Beyond Reengineering, IEEE Transactions on systems, man, and cybernetics. Part C: applications and reviews. https://doi.org/10.1109/TSMCC.2007.905812

56. vom Brocke, J.; Recker, J.; Mendling, J. 2010. Value-oriented process modeling: integrating financial perspectives into business process re-design, Business Process Management Journal 16(2): 333-356. Retrieved from https://doi.org/10.1108/14637151011035633

57. Wieland, U.; Fischer, M.; Pfitzner, M.; Hilbert, A. 2015. Process performance measurement system - towards a customer-oriented solution, Business Process Management Journal 21(2): 312-331. Retrieved from https://doi.org/10.1108/BPMJ-04-2014-0032

58. Wu, L.; Park, D. 2009. Dynamic outsourcing through process modularization, Business Process Management Journal 15(2): 225-244. Retrieved from https://doi.org/10.1108/14637150910949461

59. Wynn, M.T.; Verbeek, H.M.W.; van der Aalst, W.M.P.; ter Hofstede, A.H.M.; Edmond, D. 2009. Business process verification finally a reality!, Business Process Management Journal 15(1): 74-92. Retrieved from https://doi.org/10.1108/14637150910931479

60. Yen, V.C. 2009. An integrated model for business process measurement, Business Process Management Journal 15(6): 865-875. Retrieved from https://doi.org/10.1108/14637150911003757

61. Yu, Y.; Pelaez, A.; Lang, K.R. 2016. Designing and evaluating business process models: an experimental approach, Information Systems and e-Business Management 14: 767-789. Retrieved from http://dx.doi.org/10.1007/s10257-014-0257-0

62. Zhu, X.; Recker, J.; Zhu, G.; Santoro, F.M. 2014). Exploring location-dependency in process modeling, Business Process Management Journal 20(6): 794-815. Retrieved from https://doi.org/10.1108/BPMJ-06-2013-0066

Appendix 2. Business process attributes, elements and references $(\mathrm{N}=17)$

\begin{tabular}{|c|c|c|c|}
\hline \multicolumn{2}{|c|}{ Method and purpose of process analysis } & Findings of the & Analysis techniques \\
\hline Bekgaard, 2009 & $\begin{array}{l}\text { Event-based conceptual } \\
\text { modeling designed to improve } \\
\text { process modeling }\end{array}$ & $\begin{array}{l}\text { Guidelines for creation } \\
\text { dynamic and static models of } \\
\text { business process }\end{array}$ & \\
\hline Bergener et al., 2015 & $\begin{array}{lrr}\text { Approach } & \text { designed } & \text { to } \\
\text { facilitate the } & \text { detection of } \\
\text { pattern-based } & \text { process } \\
\text { weakness } & & \end{array}$ & $\begin{array}{l}\text { Provided tools for automated } \\
\text { detection of process } \\
\text { weaknesses applying the } \\
\text { pattern matching approach }\end{array}$ & $\begin{array}{lr}\text { Argumentative } & \text { reasoning, } \\
\text { literature } & \text { analysis, } \\
\text { conceptual } & \text { modeling, } \\
\text { interview } & \end{array}$ \\
\hline Bouchbout et al., 2012 & $\begin{array}{l}\text { Framework for modeling } \\
\text { collaborative processes }\end{array}$ & 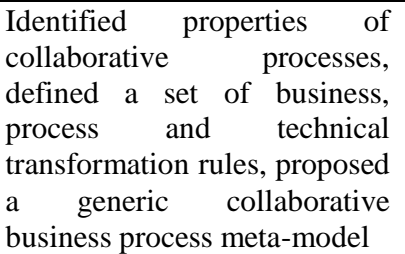 & $\begin{array}{l}\text { Model drive architecture, } \\
\text { Business process modeling } \\
\text { notation }\end{array}$ \\
\hline Cadden, Downes, 2013 & $\begin{array}{l}\text { Model of high level business } \\
\text { process designed to enable } \\
\text { supplier integration within the } \\
\text { product development }\end{array}$ & $\begin{array}{l}\text { Developed an early supplier } \\
\text { involvement business process }\end{array}$ & Case analysis \\
\hline Cardoso, 2008 & $\begin{array}{l}\text { Developed measure to } \\
\text { analyze the control-flow } \\
\text { complexity of business } \\
\text { processes }\end{array}$ & $\begin{array}{l}\text { Introduced control-flow } \\
\text { complexity measure qualified } \\
\text { as comprehensive and } \\
\text { validated }\end{array}$ & $\begin{array}{l}\text { Weyuker method for the } \\
\text { evaluation of the metric, } \\
\text { experiment for empirical } \\
\text { validation of the metric }\end{array}$ \\
\hline Climent et al., 2009 & Identification & Detected the descriptive and & Flow diagram technique, \\
\hline
\end{tabular}


The International Journal

ENTREPRENEURSHIP AND SUSTAINABILITY ISSUES

ISSN 2345-0282 (online) http://jssidoi.org/jesi/

2018 Volume 6 Number 1 (September)

http://doi.org/10.9770/jesi.2018.6.1(15)

\begin{tabular}{|c|c|c|c|}
\hline & $\begin{array}{l}\text { improvement of critical } \\
\text { processes in the bank setting }\end{array}$ & $\begin{array}{l}\text { graphical view of the critical } \\
\text { processes of a bank. }\end{array}$ & $\begin{array}{lr}\text { integrated } & \text { definitions } \\
\text { technique, } & \text { structured } \\
\text { modeling } & \\
\end{array}$ \\
\hline Corradini et al., 2015 & $\begin{array}{l}\text { Business process correctness } \\
\text { analysis, based on formal } \\
\text { unfolding method }\end{array}$ & $\begin{array}{l}\text { Identified risky unti-pattern } \\
\text { interactions in the process } \\
\text { execution }\end{array}$ & $\begin{array}{l}\text { Business process modeling } \\
\text { notation, Petri Net }\end{array}$ \\
\hline Dervitsiotis, 1999 & $\begin{array}{l}\text { Systematic approach for } \\
\text { selecting critical processes }\end{array}$ & $\begin{array}{l}\text { Identify value adding } \\
\text { contributions of the process }\end{array}$ & $\begin{array}{l}\text { Riggs matrix for combining } \\
\text { the measures of different } \\
\text { units }\end{array}$ \\
\hline Hadasch et al., 2016 & $\begin{array}{l}\text { Developed concept of } \\
\text { directive explanation, } \\
\text { designed to provide context- } \\
\text { dependent feedback to the } \\
\text { user of process IT systems }\end{array}$ & $\begin{array}{l}\text { Conceptualized and designed } \\
\text { directive explanation tool for } \\
\text { the users to follow process } \\
\text { tasks; provided the evidence } \\
\text { of the impact of directive } \\
\text { explanations on the process } \\
\text { compliance performance }\end{array}$ & $\begin{array}{l}\text { Laboratory experiment, } \\
\text { logistic regression method } \\
\text { for data analysis }\end{array}$ \\
\hline $\begin{array}{l}\text { Hanafizadeh et al., } \\
2009\end{array}$ & $\begin{array}{l}\text { Methodology for selecting } \\
\text { strategic processes in the } \\
\text { setting of investment } \\
\text { enterprise, based on the } \\
\text { Balanced Scorecard } \\
\text { framework and } \\
\text { the statistical analysis }\end{array}$ & $\begin{array}{l}\text { Identified strategic processes } \\
\text { of investment enterprise }\end{array}$ & $\begin{array}{lr}\text { Balanced } & \text { Scorecard } \\
\text { framework, } & \text { statistical } \\
\text { analysis, } & \text { questionnaire } \\
\text { survey } & \end{array}$ \\
\hline Helquist et al., 2012 & $\begin{array}{l}\text { Developed technique for } \\
\text { process uncertainty } \\
\text { identification and analysis }\end{array}$ & \begin{tabular}{lcr} 
Process & \multicolumn{2}{c}{ deployment } \\
alternatives & measured by \\
aggregated scores in regard to \\
inherent risks \\
opportunities
\end{tabular} & $\begin{array}{lrr}\text { Multiple } & \text { criteria } & \text { decision } \\
\text { analysis, virtual } & \text { process } \\
\text { simulation, } & \text { business } \\
\text { process modeling } & \end{array}$ \\
\hline Najmi, 2005 & $\begin{array}{l}\text { Framework for performance } \\
\text { measurement system review } \\
\text { designed to facilitate the } \\
\text { procedures of reviewing } \\
\text { business performance and } \\
\text { performance measurement } \\
\text { system }\end{array}$ & $\begin{array}{l}\text { Designed process of } \\
\text { reviewing, } \\
\text { activities, people, tools and } \\
\text { expected outputs }\end{array}$ & $\begin{array}{l}\text { Literature analysis, } \\
\text { technique of review card }\end{array}$ \\
\hline Quesada, Gazo, 2007 & $\begin{array}{l}\text { Methodology designed to } \\
\text { determine and rank key } \\
\text { internal business processes in } \\
\text { relationship to critical success } \\
\text { factors; }\end{array}$ & $\begin{array}{l}\text { Developed critical success } \\
\text { factors for manufacturing } \\
\text { enterprises and defined critical } \\
\text { internal processes }\end{array}$ & $\begin{array}{lr}\begin{array}{l}\text { Balanced } \\
\text { procedure, }\end{array} & \text { scoreboard } \\
\text { matrix } & \end{array}$ \\
\hline Regev et al., 2005 & $\begin{array}{l}\text { Framework for business } \\
\text { process classification; and } \\
\text { theoretical justification of } \\
\text { "Use and misuse cases" } \\
\text { technique for modeling the } \\
\text { value creation and abuse } \\
\text { preventions activities }\end{array}$ & $\begin{array}{l}\text { Regulative process activities } \\
\text { to mitigate of the explicit } \\
\text { threat from the misuse cases } \\
\text { are introduced }\end{array}$ & Process modeling \\
\hline Shang, Wu, 2013 & $\begin{array}{l}\text { Method for measuring } \\
\text { operational and managerial } \\
\text { performance } \\
\text { of process capital }\end{array}$ & $\begin{array}{l}\text { Identified indicators for the } \\
\text { value of process capital }\end{array}$ & $\begin{array}{l}\text { Hierarchical } \\
\text { analysis }\end{array}$ \\
\hline $\begin{array}{l}\text { Solaimani, Bouwman, } \\
2012\end{array}$ & $\begin{array}{l}\text { Conceptual framework of } \\
\text { business model and business } \\
\text { process alignment }\end{array}$ & 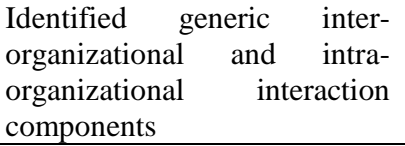 & Literature analysis \\
\hline Torres, Sidorova, 2015 & $\begin{array}{l}\text { Process configuration } \\
\text { features, such as process rules } \\
\text { complexity, work backlog, }\end{array}$ & $\begin{array}{l}\text { Provided the evidence of the } \\
\text { work setting effect on } \\
\text { employees motivation }\end{array}$ & $\begin{array}{l}\text { Experiment, questionnaire } \\
\text { survey }\end{array}$ \\
\hline
\end{tabular}




\begin{tabular}{|l|l|l|l|}
\hline & $\begin{array}{l}\text { and case distribution method, } \\
\text { evaluated in regard to the } \\
\text { impact on motivation of } \\
\text { process participants }\end{array}$ & & \\
\hline
\end{tabular}

Appendix 3. Frameworks, methods and techniques for business process analysis $(\mathrm{N}=51)$

\begin{tabular}{|c|c|c|c|c|}
\hline \multicolumn{2}{|c|}{ Method and purpose of process analysis } & \multirow{2}{*}{$\begin{array}{l}\text { Findings of the process } \\
\text { analysis }\end{array}$} & \multirow{2}{*}{$\begin{array}{l}\text { Analysis techniques } \\
\text { Case study }\end{array}$} & \multirow{2}{*}{$\begin{array}{l}\text { Generalized process } \\
\text { investigation } \\
\text { directions in relation to } \\
\text { the research question }\end{array}$} \\
\hline $\begin{array}{ll}\text { Abu Rub, Issa, } \\
2012\end{array}$ & $\begin{array}{l}\text { Developed approach to } \\
\text { exploring complex } \\
\text { processes using business } \\
\text { process modeling }\end{array}$ & & & \\
\hline Alfaro et al., 2009 & $\begin{array}{l}\text { Defined core criteria } \\
\text { characteristics for } \\
\text { performance } \\
\text { measurement systems, } \\
\text { which cover business } \\
\text { process interoperability } \\
\text { requirements }\end{array}$ & $\begin{array}{l}\text { Identified characteristics } \\
\text { of performance } \\
\text { measurement systems to } \\
\text { tackle business processes } \\
\text { interoperability }\end{array}$ & Literature review & $\begin{array}{ll}\text { Business } & \text { process } \\
\text { performance } & \\
\text { measurement } & \end{array}$ \\
\hline $\begin{array}{l}\text { Anastassiu et al., } \\
2016\end{array}$ & $\begin{array}{l}\text { Procedural guide for } \\
\text { analyzing business } \\
\text { process ontological } \\
\text { transactions in order to } \\
\text { identify context } \\
\text { information relevant to } \\
\text { process }\end{array}$ & $\begin{array}{l}\text { Identified attributes } \\
\text { impacting the goal of the } \\
\text { process; elements of the } \\
\text { immediate/internal } \\
\text { context are considered as } \\
\text { attributes }\end{array}$ & $\begin{array}{l}\text { Business process modeling, } \\
\text { questionnaire survey to } \\
\text { identify the essential } \\
\text { activities of a process, } \\
\text { ontological transaction } \\
\text { matrix for identification of an } \\
\text { ontological transaction }\end{array}$ & $\begin{array}{l}\text { Improvement of the } \\
\text { process as a tool intended } \\
\text { to generate performance }\end{array}$ \\
\hline $\begin{array}{l}\text { Andersson et al., } \\
2005\end{array}$ & $\begin{array}{l}\text { Method of definition of } \\
\text { best practice business } \\
\text { process pattern designed } \\
\text { for comparison with the } \\
\text { process }\end{array}$ & $\begin{array}{l}\text { Proposed method aimed } \\
\text { to define process pattern } \\
\text { designed to be used for a } \\
\text { re-engineering of the } \\
\text { process }\end{array}$ & $\begin{array}{l}\text { State-flow common method } \\
\text { for business modelling is } \\
\text { used to determine the process } \\
\text { pattern }\end{array}$ & $\begin{array}{l}\text { Improvement of the } \\
\text { process as a tool intended } \\
\text { to generate performance }\end{array}$ \\
\hline Berente et al., 2009 & $\begin{array}{l}\text { Principles of process } \\
\text { integration }\end{array}$ & $\begin{array}{l}\text { Identified generalized } \\
\text { activities that describe } \\
\text { common non-integrated } \\
\text { behavior }\end{array}$ & $\begin{array}{l}\text { Literature analysis, field } \\
\text { studies }\end{array}$ & $\begin{array}{l}\text { Business process as part } \\
\text { of value chain }\end{array}$ \\
\hline $\begin{array}{l}\text { Bergener et al., } \\
2015\end{array}$ & $\begin{array}{l}\text { "Pattern-based approach } \\
\text { for automatically } \\
\text { detecting potential } \\
\text { process weaknesses in } \\
\text { semantic process models" } \\
\text { (Bergener et al., 2015, } \\
\text { p.25) }\end{array}$ & $\begin{array}{l}\text { Process weaknesses } \\
\text { identified automatically } \\
\text { due to application of } \\
\text { process weakness patterns } \\
\text { to semantic process } \\
\text { models. }\end{array}$ & $\begin{array}{l}\text { Generic model query } \\
\text { language, design science } \\
\text { research process to combine, } \\
\text { apply and evaluate IT } \\
\text { artifacts }\end{array}$ & $\begin{array}{l}\text { Improvement of the } \\
\text { process as a tool intended } \\
\text { to generate performance }\end{array}$ \\
\hline Bisogno et al., 2016 & $\begin{array}{l}\text { Method, based on } \\
\text { Business Process } \\
\text { Modeling and Notation } \\
\text { and Business Process } \\
\text { Simulation, designed to } \\
\text { measure key performance } \\
\text { indicators of the process } \\
\text { and to test potential } \\
\text { process improvements }\end{array}$ & $\begin{array}{l}\text { Identified process } \\
\text { weaknesses and possible } \\
\text { corrective actions }\end{array}$ & 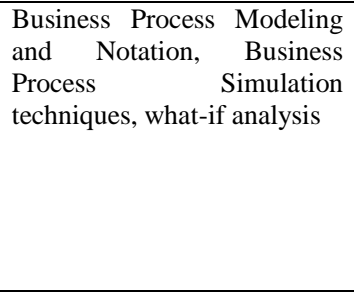 & $\begin{array}{l}\text { Improvement of the } \\
\text { process as a tool intended } \\
\text { to generate performance }\end{array}$ \\
\hline $\begin{array}{l}\text { Bocciarelli, } \\
\text { D'Ambrogio, } 2014\end{array}$ & $\begin{array}{l}\text { Model-driven method, } \\
\text { that exploits } \\
\text { performability enabled } \\
\text { BPMN, designed to enact } \\
\text { automated analysis of }\end{array}$ & $\begin{array}{l}\text { Provide the availability to } \\
\text { predict process behavior }\end{array}$ & $\begin{array}{l}\text { Standard BPMN meta-model } \\
\text { enriched with Real Time } \\
\text { Embedded System } \\
\text { (MARTE), used for } \\
\text { description of process }\end{array}$ & $\begin{array}{l}\text { Improvement of the } \\
\text { process as a tool intended } \\
\text { to generate performance }\end{array}$ \\
\hline
\end{tabular}


The International Journal

ENTREPRENEURSHIP AND SUSTAINABILITY ISSUES

ISSN 2345-0282 (online) http://jssidoi.org/jesi/ 2018 Volume 6 Number 1 (September)

http://doi.org/10.9770/jesi.2018.6.1(15)

\begin{tabular}{|c|c|c|c|c|}
\hline & $\begin{array}{l}\text { business process behavior } \\
\text { (o to predict the } \\
\text { performance } \\
\text { and the reliability of a } \\
\text { business process, either to } \\
\text { select the process } \\
\text { configuration that } \\
\text { provides the best behavior } \\
\text { or to check if a given } \\
\text { configuration satisfies the } \\
\text { overall } \\
\text { requirements) }\end{array}$ & & $\begin{array}{l}\text { performance attributes and } \\
\text { expanded with additional } \\
\text { contributions that add the } \\
\text { description of reliability } \\
\text { properties, reliability of } \\
\text { process is considered in term } \\
\text { of faults and failures that } \\
\text { may affect the process } \\
\text { execution }\end{array}$ & \\
\hline $\begin{array}{l}\text { Bolsinger et al., } \\
2015\end{array}$ & $\begin{array}{l}\text { Decision model that } \\
\text { determines the routing of } \\
\text { the instances of the } \\
\text { process in a way that } \\
\text { ensures maximum value } \\
\text { contribution to the } \\
\text { process }\end{array}$ & $\begin{array}{l}\text { Determined parameters } \\
\text { that maximizes the } \\
\text { expected cash flow of the } \\
\text { process }\end{array}$ & $\begin{array}{l}\text { Business process modeling, } \\
\text { scoring system for the } \\
\text { estimation of risk level }\end{array}$ & $\begin{array}{l}\text { Improvement of the } \\
\text { process as a tool intended } \\
\text { to generate performance }\end{array}$ \\
\hline $\begin{array}{l}\text { Bosch-Mauchand et } \\
\text { al., } 2013\end{array}$ & $\begin{array}{l}\text { Method and tools } \\
\text { designed to evaluate } \\
\text { manufacturing enterprise } \\
\text { processes in } \\
\text { terms of performance and } \\
\text { value indicators based on } \\
\text { knowledge management } \\
\text { integration }\end{array}$ & $\begin{array}{l}\text { Product life-cycle } \\
\text { management - knowledge } \\
\text { management framework } \\
\text { for automated assessment } \\
\text { of enterprise performance }\end{array}$ & $\begin{array}{l}\text { Analytic hierarchy process } \\
\text { technique used for } \\
\text { constructing a value indicator }\end{array}$ & $\begin{array}{l}\text { Improvement of the } \\
\text { process as a tool intended } \\
\text { to generate performance }\end{array}$ \\
\hline vom Brocke, 2010 & $\begin{array}{l}\text { Value-oriented approach } \\
\text { to business process } \\
\text { modeling }\end{array}$ & $\begin{array}{l}\text { Framework designed to } \\
\text { integrate financial } \\
\text { information into process } \\
\text { re-design. }\end{array}$ & Balanced scorecard approach & $\begin{array}{l}\text { Improvement of the } \\
\text { process as a tool intended } \\
\text { to generate performance }\end{array}$ \\
\hline Chin, Saman, 2004 & $\begin{array}{l}\text { Method designed to } \\
\text { identify performance } \\
\text { measures for quantitative } \\
\text { analysis and selection of } \\
\text { production system }\end{array}$ & $\begin{array}{l}\text { Performance rating for } \\
\text { each production system } \\
\text { are calculated }\end{array}$ & $\begin{array}{l}\text { Questionnaire survey } \\
\text { technique (based on } \\
\text { manufacturing outputs of } \\
\text { cost, quality, performance, } \\
\text { delivery, flexibility, } \\
\text { innovativeness) was used for } \\
\text { the identification of } \\
\text { performance measure }\end{array}$ & $\begin{array}{ll}\text { Business } & \text { process } \\
\text { performance } & \\
\text { measurement } & \end{array}$ \\
\hline $\begin{array}{l}\text { Corradini et al., } \\
2015\end{array}$ & $\begin{array}{l}\text { Approach for the } \\
\text { assessment of inter- } \\
\text { organizational business } \\
\text { processes' structural } \\
\text { properties in public } \\
\text { administrations domain }\end{array}$ & $\begin{array}{l}\text { Explored the possibilities } \\
\text { of formal verification } \\
\text { techniques in order to } \\
\text { assess the properties of } \\
\text { business process models }\end{array}$ & $\begin{array}{l}\text { Business process model } \\
\text { defined by Business Process } \\
\text { Model and Notation is } \\
\text { transformed to Petri Net } \\
\text { standard, verification of } \\
\text { derived process in terms of } \\
\text { desired properties is carried } \\
\text { out using net unfolding } \\
\text { approach }\end{array}$ & $\begin{array}{l}\text { Improvement of the } \\
\text { process as a tool intended } \\
\text { to generate performance }\end{array}$ \\
\hline Coskun et al., 2008 & $\begin{array}{l}\text { Model designed to } \\
\text { determine and analyze the } \\
\text { weak points of the process } \\
\text { and reducing the } \\
\text { weakness } \\
\text { degrees }\end{array}$ & $\begin{array}{l}\text { Developed a tool intended } \\
\text { to facilitate decision } \\
\text { making }\end{array}$ & $\begin{array}{l}\text { Analytic hierarchy process } \\
\text { methodology, goal } \\
\text { programming, linear } \\
\text { programming }\end{array}$ & $\begin{array}{l}\text { Improvement of the } \\
\text { process as a tool intended } \\
\text { to generate performance }\end{array}$ \\
\hline $\begin{array}{l}\text { Darmani, } \\
\text { Hanafizadeh, } 2013\end{array}$ & $\begin{array}{l}\text { Methodology for business } \\
\text { process portfolio } \\
\text { selection, designed to } \\
\text { support the selection of } \\
\text { the processes for process } \\
\text { reengineering (BPR). }\end{array}$ & $\begin{array}{l}\text { Proposed methodology } \\
\text { aims to identify the } \\
\text { process, achieving lower } \\
\text { risk and higher } \\
\text { probability of success for } \\
\text { BPR projects. }\end{array}$ & $\begin{array}{l}\text { BSC method for selection of } \\
\text { strategic processes, } \\
\text { questionnaire survey of } \\
\text { experts for the evaluation of } \\
\text { importance of each process, } \\
\text { perceived degree of change, } \\
\text { and also for the evaluation of } \\
\text { risk and return for BPR } \\
\text { project and BPR scenario, } \\
\text { multiple criteria decision } \\
\text { making method for process }\end{array}$ & $\begin{array}{l}\text { Improvement of the } \\
\text { process performance } \\
\text { impact on business } \\
\text { performance }\end{array}$ \\
\hline
\end{tabular}


The International Journal

ENTREPRENEURSHIP AND SUSTAINABILITY ISSUES

ISSN 2345-0282 (online) http://jssidoi.org/jesi/

2018 Volume 6 Number 1 (September)

http://doi.org/10.9770/jesi.2018.6.1(15)

\begin{tabular}{|c|c|c|c|c|}
\hline & & & $\begin{array}{l}\text { ranking, technique for order } \\
\text { preference by similarity to } \\
\text { ideal solution (TOPSIS) for } \\
\text { prioritizing the processes }\end{array}$ & \\
\hline $\begin{array}{l}\text { Davamanirajan et } \\
\text { al., } 2006\end{array}$ & $\begin{array}{l}\text { Process performance } \\
\text { model designed to } \\
\text { assess the effect of } \\
\text { process' IT system on } \\
\text { the process output and } \\
\text { quality; economic } \\
\text { performance model } \\
\text { designed to link process } \\
\text { performance with the } \\
\text { firm's performance }\end{array}$ & $\begin{array}{l}\text { Elements of the process } \\
\text { performance model and } \\
\text { economic performance } \\
\text { model are defined, Trade } \\
\text { services process model } \\
\text { variables identified }\end{array}$ & $\begin{array}{l}\text { OLS regression for the } \\
\text { estimation of model } \\
\text { equations }\end{array}$ & $\begin{array}{l}\text { Improvement of the } \\
\text { process as a tool intended } \\
\text { to generate performance }\end{array}$ \\
\hline Dervitsiotis, 1999 & $\begin{array}{l}\text { Method for selecting } \\
\text { critical processes with the } \\
\text { greatest impact on } \\
\text { organizations goals }\end{array}$ & $\begin{array}{l}\text { Assessment of weighted } \\
\text { process contribution score } \\
\text { and ranking of the } \\
\text { processes in terms of total } \\
\text { weighted contribution }\end{array}$ & $\begin{array}{l}\text { Weighted performance level } \\
\text { calculation method to assess } \\
\text { the weighted process } \\
\text { contribution reflecting the } \\
\text { impact of the process to } \\
\text { strategic goal, Riggs matrix } \\
\text { applied for transformation of } \\
\text { process performance } \\
\text { measures to common } \\
\text { numerical performance scale }\end{array}$ & $\begin{array}{l}\text { Improvement of the } \\
\text { process performance } \\
\text { impact on business } \\
\text { performance }\end{array}$ \\
\hline $\begin{array}{l}\text { Espino-Rodriguez, } \\
\text { Rodriguez-Diaz, } \\
2014\end{array}$ & $\begin{array}{l}\text { Methodology designed to } \\
\text { identify operations that } \\
\text { generate core } \\
\text { competences within the } \\
\text { supply chain process }\end{array}$ & $\begin{array}{l}\text { Identified operations in } \\
\text { terms of their ability to be } \\
\text { a source of competitive } \\
\text { advantage }\end{array}$ & $\begin{array}{l}\text { Supply chain operations } \\
\text { reference model, } \\
\text { questionnaire survey, } \\
\text { structural equation modelling }\end{array}$ & $\begin{array}{l}\text { Improvement of the } \\
\text { process performance } \\
\text { impact on business } \\
\text { performance }\end{array}$ \\
\hline $\begin{array}{l}\text { Franceschini et al., } \\
2013\end{array}$ & $\begin{array}{l}\text { Methodology designed to } \\
\text { evaluate the impact of } \\
\text { performance } \\
\text { measurement system on } \\
\text { the organization } \\
\text { performance }\end{array}$ & $\begin{array}{l}\text { Proposed impact } \\
\text { reference model, based on } \\
\text { the balance scorecard } \\
\text { framework }\end{array}$ & $\begin{array}{l}\text { A series of case studies } \\
\text { applied for the evaluation of } \\
\text { the sets of performance } \\
\text { indicators }\end{array}$ & $\begin{array}{l}\text { Improvement of the } \\
\text { process performance } \\
\text { impact on business } \\
\text { performance }\end{array}$ \\
\hline Gonzalez, 2010 & $\begin{array}{l}\text { Generalization of the } \\
\text { trends in research on } \\
\text { business process } \\
\text { measurement }\end{array}$ & & Systematic literature review & $\begin{array}{ll}\text { Business } & \text { process } \\
\text { performance } & \\
\text { measurement } & \end{array}$ \\
\hline $\begin{array}{l}\text { Hachicha et al., } \\
2016\end{array}$ & $\begin{array}{l}\text { Analysis and assessment } \\
\text { approach for collaborative } \\
\text { business } \\
\text { processes in the service- } \\
\text { oriented architecture }\end{array}$ & $\begin{array}{l}\text { Proposed method to track } \\
\text { the execution of } \\
\text { collaborative business } \\
\text { process and to analyse } \\
\text { the performance trajectory } \\
\text { of a business process } \\
\text { regarding the business } \\
\text { performance level }\end{array}$ & $\begin{array}{lr}\text { Business process } & \text { modeling } \\
\text { notation for process } & \text { pros } \\
\text { structuring, KPIs for business } \\
\text { performance r goal } \\
\text { measurement, reference } \\
\text { analysis framework for } \\
\text { measurement of technical } \\
\text { indicators }\end{array}$ & $\begin{array}{l}\text { Connection between the } \\
\text { performance of the } \\
\text { process and the } \\
\text { performance of the } \\
\text { business }\end{array}$ \\
\hline Hadasch et al., 2016 & $\begin{array}{l}\text { Concept of directive } \\
\text { explanations to the user of } \\
\text { the process' information } \\
\text { system so that the } \\
\text { individual user complies } \\
\text { with the process }\end{array}$ & $\begin{array}{l}\text { The influence of directive } \\
\text { explanations to the users' } \\
\text { compliance performance } \\
\text { is confirmed by the } \\
\text { experiment }\end{array}$ & $\begin{array}{l}\text { Laboratory experiment to test } \\
\text { user's process compliance } \\
\text { performance }\end{array}$ & $\begin{array}{l}\text { Improvement of the } \\
\text { process as a tool intended } \\
\text { to generate performance }\end{array}$ \\
\hline Helquist et al., 2009 & $\begin{array}{l}\text { Development of virtual } \\
\text { process simulation } \\
\text { technique for } \\
\text { modeling process } \\
\text { alternatives }\end{array}$ & $\begin{array}{l}\text { Process modeling method } \\
\text { developed }\end{array}$ & Business process developing & $\begin{array}{l}\text { Improvement of the } \\
\text { process as a tool intended } \\
\text { to generate performance }\end{array}$ \\
\hline $\begin{array}{l}\text { Khan, Wibisono, } \\
2008\end{array}$ & $\begin{array}{l}\text { Knowledge-based } \\
\text { performance } \\
\text { measurement system }\end{array}$ & $\begin{array}{l}\text { Developed measurement } \\
\text { system covering various } \\
\text { perspectives of } \\
\text { company performance: } \\
\text { business perspective, } \\
\text { customer perspective, }\end{array}$ & $\begin{array}{l}\text { Analytic hierarchy process } \\
\text { methodology, gap analysis }\end{array}$ & $\begin{array}{l}\text { Business } \\
\text { performance } \\
\text { measurement }\end{array}$ \\
\hline
\end{tabular}




\begin{tabular}{|c|c|c|c|c|}
\hline & & $\begin{array}{l}\text { manufacturing } \\
\text { competitive priorities } \\
\text { perspective, } \\
\text { internal process } \\
\text { s perspective and resource } \\
\text { and method availability } \\
\text { perspective }\end{array}$ & & \\
\hline Kohlbacher, 2010 & $\begin{array}{l}\text { Literature review of } \\
\text { studies of the influence of } \\
\text { the process orientation on } \\
\text { organizational } \\
\text { performance }\end{array}$ & & Literature review & $\begin{array}{l}\text { Connection between the } \\
\text { performance of the } \\
\text { process and the } \\
\begin{array}{l}\text { performance of } \\
\text { business }\end{array}\end{array}$ \\
\hline $\begin{array}{l}\text { Kohlbacher, } \\
\text { Gruenwald, } 2011\end{array}$ & $\begin{array}{l}\text { Model to measure the key } \\
\text { dimensions of the process } \\
\text { orientation construct }\end{array}$ & $\begin{array}{l}\text { Developed } \\
\text { multidimensional } \\
\text { construct of process } \\
\text { orientation }\end{array}$ & $\begin{array}{l}\text { Literature review, factor } \\
\text { analysis }\end{array}$ & $\begin{array}{l}\text { Connection between the } \\
\text { performance of the } \\
\text { process and the } \\
\begin{array}{l}\text { performance of the } \\
\text { business }\end{array}\end{array}$ \\
\hline Lee et al., 2005 & $\begin{array}{l}\text { "Method for evaluation of } \\
\text { business process } \\
\text { alternatives focusing on } \\
\text { demand chain needs" } \\
\text { (Lee et al., 2005, p.198) }\end{array}$ & $\begin{array}{l}\text { Evaluated expected } \\
\text { impact of the alternatives } \\
\text { considering all criteria, on } \\
\text { which alternatives are } \\
\text { being compared }\end{array}$ & Multiple criteria analysis & $\begin{array}{l}\text { Improvement of the } \\
\text { process performance } \\
\text { impact on business } \\
\text { performance }\end{array}$ \\
\hline Li, Zhou, 2004 & $\begin{array}{l}\text { Framework for workflow } \\
\text { modeling and analysis }\end{array}$ & $\begin{array}{l}\text { Provided solution for the } \\
\text { automatic analysis of } \\
\text { workflow }\end{array}$ & $\begin{array}{l}\text { Generalized stochastic Petri } \\
\text { Net modeling tool is used to } \\
\text { model workflow, } \\
\text { multidimensional workflow } \\
\text { net was developed for the } \\
\text { framework }\end{array}$ & $\begin{array}{l}\text { Improvement of the } \\
\text { process as a tool intended } \\
\text { to generate performance }\end{array}$ \\
\hline $\begin{array}{l}\text { van Looy, } \\
\text { Shafagatova, } 2016\end{array}$ & $\begin{array}{l}\text { Literature review aims to } \\
\text { find patterns or trends in } \\
\text { the research on business } \\
\text { process performance } \\
\text { measurement. Provide an } \\
\text { extended list of } 140 \\
\text { process-related } \\
\text { performance indicators in } \\
\text { a systematic manner by } \\
\text { further categorizing them } \\
\text { into } 11 \text { performance } \\
\text { perspectives, distinguish } \\
\text { between models focusing } \\
\text { on the entire business and } \\
\text { models of single process }\end{array}$ & $\begin{array}{l}\text { Structured literature } \\
\text { review }\end{array}$ & $\begin{array}{l}\text { Meta study method, } \\
\text { structured literature review } \\
\text { based on bibliometric type of } \\
\text { content analysis }\end{array}$ & $\begin{array}{ll}\text { Business } & \text { process } \\
\text { performance } & \\
\text { measurement } & \end{array}$ \\
\hline $\begin{array}{l}\text { McCormack, } \\
\text { Rauseo, } 2005\end{array}$ & $\begin{array}{l}\text { Method for aligning } \\
\text { business strategy to } \\
\text { process strategy and } \\
\text { design by using cognitive } \\
\text { mapping techniques and } \\
\text { principles of modularity }\end{array}$ & $\begin{array}{l}\text { Proposed method for } \\
\text { developing high-level } \\
\text { business process } \\
\text { orientation, defined a } \\
\text { generic high level process } \\
\text { map, identified process } \\
\text { types }\end{array}$ & $\begin{array}{l}\text { Cognitive mapping and } \\
\text { principles of modularity }\end{array}$ & $\begin{array}{l}\text { Improvement of the } \\
\text { process performance } \\
\text { impact on business } \\
\text { performance }\end{array}$ \\
\hline Morgan, 2004 & $\begin{array}{l}\text { Paper aims to assess } \\
\text { performance } \\
\text { measurement in supply } \\
\text { chain and provide insights } \\
\text { for improving supply } \\
\text { chain performance } \\
\text { measurement }\end{array}$ & $\begin{array}{l}\text { Literature analysis } \\
\text { Identified requirements } \\
\text { for supply chain } \\
\text { performance } \\
\text { measurement system }\end{array}$ & Literature analysis & $\begin{array}{ll}\text { Business } & \text { process } \\
\text { performance } & \\
\text { measurement } & \end{array}$ \\
\hline Nestic et al., 2015 & $\begin{array}{l}\text { Fuzzy model for } \\
\text { evaluation and } \\
\text { improvement of process } \\
\text { quality }\end{array}$ & $\begin{array}{l}\text { Developed solution for } \\
\text { process quality } \\
\text { assessment }\end{array}$ & $\begin{array}{l}\text { genetic algorithm approach } \\
\text { applied for solution } \\
\text { development, fuzzy pair-vice } \\
\text { comparison matrices } \\
\text { technique used for } \\
\text { calculation of fuzzy ratings } \\
\text { of key performance } \\
\text { indicators }\end{array}$ & $\begin{array}{l}\text { Improvement of the } \\
\text { process as a tool intended } \\
\text { to generate performance }\end{array}$ \\
\hline
\end{tabular}


The International Journal

ENTREPRENEURSHIP AND SUSTAINABILITY ISSUES

ISSN 2345-0282 (online) http://jssidoi.org/jesi/

2018 Volume 6 Number 1 (September)

http://doi.org/10.9770/jesi.2018.6.1(15)

\begin{tabular}{|c|c|c|c|c|}
\hline Nichlods, Mo, 2016 & $\begin{array}{l}\text { Proposed method aims to } \\
\text { indicate a link between } \\
\text { the improvement } \\
\text { capability of an } \\
\text { organization and the } \\
\text { intensity of effort applied } \\
\text { to a business process } \\
\text { improvement (BPI) } \\
\text { project }\end{array}$ & $\begin{array}{l}\text { Function that estimates } \\
\text { the applicable effort } \\
\text { expressed as regression } \\
\text { function of current } \\
\text { organization's } \\
\text { improvement capability }\end{array}$ & $\begin{array}{l}\text { Defined capability factor } \\
\text { hierarchal structure, } \\
\text { relationship between } \\
\text { capability to the effectiveness } \\
\text { and performance to } \\
\text { effectiveness approximated } \\
\text { by regression analysis }\end{array}$ & $\begin{array}{l}\text { Improvement of the } \\
\text { process performance } \\
\text { impact on business } \\
\text { performance }\end{array}$ \\
\hline $\begin{array}{l}\text { de Padua et al., } \\
2014\end{array}$ & $\begin{array}{l}\text { Comparative analysis of } \\
\text { methods of process } \\
\text { modeling and root cause } \\
\text { analysis in the application } \\
\text { for diagnostics of } \\
\text { information management } \\
\text { process }\end{array}$ & $\begin{array}{l}\text { Recommendations for } \\
\text { applying the methods in } \\
\text { process analysis practice }\end{array}$ & $\begin{array}{l}\text { Business process modeling } \\
\text { notation technique applied } \\
\text { for process modeling, current } \\
\text { reality tree technique applied } \\
\text { for root cause analysis, } \\
\text { experiment for the testing of } \\
\text { process diagnosis techniques }\end{array}$ & $\begin{array}{l}\text { Improvement of the } \\
\text { process as a tool intended } \\
\text { to generate performance }\end{array}$ \\
\hline Padua et al., 2015 & $\begin{array}{l}\text { Conceptual } \\
\text { recommendations for } \\
\text { the development of } \\
\text { sustainability } \\
\text { performance } \\
\text { measurement system } \\
\text { based on business } \\
\text { process perspective }\end{array}$ & & Literature review & $\begin{array}{ll}\text { Business } & \text { process } \\
\text { performance } & \\
\text { measurement } & \end{array}$ \\
\hline Pun et al., 2012 & $\begin{array}{l}\text { Approach for analyzing } \\
\text { key performance } \\
\text { indicators of traffic } \\
\text { intensive web-enabled } \\
\text { business processes based } \\
\text { on internal and external } \\
\text { view of performance }\end{array}$ & $\begin{array}{l}\text { Key performance } \\
\text { indicators of traffic } \\
\text { intensive web-enabled } \\
\text { business processes } \\
\text { identified }\end{array}$ & $\begin{array}{l}\text { Audit trail analysis, stress } \\
\text { testing, workflow schema }\end{array}$ & $\begin{array}{ll}\text { Business } & \text { process } \\
\text { performance } & \\
\text { measurement } & \end{array}$ \\
\hline Robson, 2004 & $\begin{array}{l}\text { Criteria for the evaluation } \\
\text { of process measurement } \\
\text { systems in relation to } \\
\text { potential of the process } \\
\text { performance } \\
\text { measurement system to } \\
\text { induce the process } \\
\text { performance } \\
\text { improvement }\end{array}$ & $\begin{array}{l}\text { Provide the steps for the } \\
\text { development of unified } \\
\text { measurement approach to } \\
\text { improving process } \\
\text { performance }\end{array}$ & $\begin{array}{l}\text { Analysis and synthesis of } \\
\text { literature sources }\end{array}$ & $\begin{array}{ll}\text { Business } & \text { process } \\
\text { performance } & \\
\text { measurement } & \end{array}$ \\
\hline $\begin{array}{l}\text { Samaranayake, } \\
2009\end{array}$ & $\begin{array}{l}\text { Framework of integrated } \\
\text { approach to business } \\
\text { process modeling }\end{array}$ & $\begin{array}{l}\text { Developed framework, } \\
\text { based on process } \\
\text { integration } \\
\text { for functional } \\
\text { applications, automation } \\
\text { for business workflows, } \\
\text { and additional } \\
\text { functionalities for } \\
\text { process optimization, was } \\
\text { applied to the enterprise } \\
\text { resource planning } \\
\text { processes }\end{array}$ & $\begin{array}{l}\text { Event-driven process chain } \\
\text { methodology }\end{array}$ & $\begin{array}{l}\text { Improvement of the } \\
\text { process as a tool intended } \\
\text { to generate performance }\end{array}$ \\
\hline $\begin{array}{l}\text { Samaranayake et } \\
\text { al., } 2015\end{array}$ & $\begin{array}{l}\text { Business process } \\
\text { reengineering framework } \\
\text { for process evaluation and } \\
\text { the improvement of } \\
\text { patient flow in health care } \\
\text { setting }\end{array}$ & $\begin{array}{l}\text { Identified key process } \\
\text { variables, modelled } \\
\text { simulating patient flow }\end{array}$ & $\begin{array}{l}\text { Mathematical modelling, } \\
\text { simulation }\end{array}$ & $\begin{array}{l}\text { Improvement of the } \\
\text { process as a tool intended } \\
\text { to generate performance }\end{array}$ \\
\hline Sarkis et al., 2006 & $\begin{array}{l}\text { Methodology for business } \\
\text { process evaluation, } \\
\text { covering the } \\
\text { environmental } \\
\text { implications of } \\
\text { technological processes }\end{array}$ & $\begin{array}{l}\text { Final aggregate } \\
\text { and normalized } \\
\text { environmental } \\
\text { consumption score (TPI), } \\
\text { calculated for each } \\
\text { process, define which } \\
\text { alternative process or } \\
\end{array}$ & $\begin{array}{l}\text { Activity based costing } \\
\text { technique, analytic hierarchy } \\
\text { process, business process } \\
\text { modeling }\end{array}$ & $\begin{array}{l}\text { Business } \\
\text { performance } \\
\text { measurement }\end{array}$ \\
\hline
\end{tabular}


The International Journal

ENTREPRENEURSHIP AND SUSTAINABILITY ISSUES

ISSN 2345-0282 (online) http://jssidoi.org/jesi/

2018 Volume 6 Number 1 (September)

http://doi.org/10.9770/jesi.2018.6.1(15)

\begin{tabular}{|c|c|c|c|c|}
\hline & & $\begin{array}{l}\text { technology is more } \\
\text { economically and } \\
\text { environmentally } \\
\text { sound }\end{array}$ & & \\
\hline $\begin{array}{l}\text { Solaimani, } \\
\text { Bouwman, } 2012\end{array}$ & $\begin{array}{l}\text { Conceptual framework of } \\
\text { business model and } \\
\text { business process } \\
\text { alignment }\end{array}$ & $\begin{array}{l}\text { Identified generic inter- } \\
\text { organizational and intra- } \\
\text { organizational interaction } \\
\text { components }\end{array}$ & Literature analysis & $\begin{array}{l}\text { Business process as part } \\
\text { of value chain }\end{array}$ \\
\hline $\begin{array}{l}\text { Torres, Sidorova, } \\
2015\end{array}$ & $\begin{array}{l}\text { The effect of business } \\
\text { process configuration on } \\
\text { process participant's } \\
\text { motivation }\end{array}$ & $\begin{array}{l}\text { Business process } \\
\text { configuration, determined } \\
\text { by business process rules } \\
\text { complexity, work } \\
\text { backlog, and case } \\
\text { distribution method, } \\
\text { influence motivation } \\
\text { through the effect of } \\
\text { perceived competence }\end{array}$ & $\begin{array}{l}\text { Experiment, questionnaire } \\
\text { survey }\end{array}$ & $\begin{array}{l}\text { Improvement of the } \\
\text { process as a tool intended } \\
\text { to generate performance }\end{array}$ \\
\hline $\begin{array}{l}\text { Valiris, Glykas, } \\
2004\end{array}$ & $\begin{array}{l}\text { Explores Agent } \\
\text { relationship morphism } \\
\text { analysis framework for } \\
\text { business analysis, } \\
\text { inclusive structural, } \\
\text { behavioral and process } \\
\text { perspectives }\end{array}$ & & $\begin{array}{l}\text { Different analysis techniques } \\
\text { from various disciplines are } \\
\text { included in Agent } \\
\text { relationship morphism } \\
\text { analysis }\end{array}$ & $\begin{array}{l}\text { Improvement of the } \\
\text { process performance } \\
\text { impact on business } \\
\text { performance }\end{array}$ \\
\hline Vergidis et al., 2008 & $\begin{array}{l}\text { Classification of business } \\
\text { process modeling } \\
\text { techniques in terms of } \\
\text { process analysis and } \\
\text { optimization }\end{array}$ & & Literature review & $\begin{array}{l}\text { Improvement of the } \\
\text { process as a tool intended } \\
\text { to generate performance }\end{array}$ \\
\hline Wieland et al., 2015 & $\begin{array}{l}\text { Conceptual } \\
\text { recommendations for the } \\
\text { development of process } \\
\text { performance } \\
\text { measurement system } \\
\text { based on customer } \\
\text { oriented solution }\end{array}$ & & Literature review & $\begin{array}{ll}\text { Business } & \text { process } \\
\text { performance } & \\
\text { measurement } & \end{array}$ \\
\hline Wu, Park, 2009 & $\begin{array}{l}\text { Dynamic outsourcing } \\
\text { framework for making } \\
\text { and implementing process } \\
\text { outsourcing decisions }\end{array}$ & \begin{tabular}{lc} 
Developed & \multicolumn{2}{r}{ theoretical } \\
framework intended to \\
improve outsourcing \\
activities at the \\
operational level
\end{tabular} & Literature review & $\begin{array}{l}\text { Business process as part } \\
\text { of value chain }\end{array}$ \\
\hline Wynn et al., 2009 & $\begin{array}{l}\text { Verification techniques } \\
\text { designed to assess } \\
\text { correctness of business } \\
\text { process models }\end{array}$ & $\begin{array}{l}\text { Developed process } \\
\text { verification techniques }\end{array}$ & $\begin{array}{l}\text { Workflow language yet } \\
\text { another workflow language } \\
\text { (YAWL) }\end{array}$ & $\begin{array}{l}\text { Improvement of the } \\
\text { process as a tool intended } \\
\text { to generate performance }\end{array}$ \\
\hline Yarrar, 2004 & $\begin{array}{l}\text { Tendencies of } \\
\text { performance } \\
\text { measurement } \\
\text { development explored }\end{array}$ & & $\begin{array}{l}\text { Analysis and synthesis of } \\
\text { literature sources }\end{array}$ & $\begin{array}{ll}\text { Business } & \text { process } \\
\text { performance } & \\
\text { measurement } & \end{array}$ \\
\hline Yu et al., 2016 & $\begin{array}{l}\text { Experimental approach to } \\
\text { compare the alternatives } \\
\text { of business process } \\
\text { designs }\end{array}$ & $\begin{array}{l}\text { Experimental evaluation } \\
\text { of alternative business } \\
\text { process designs in } \\
\text { laboratory setting, process } \\
\text { performance evaluation } \\
\text { (data retrieval) based on } \\
\text { the experimental } \\
\text { economics methods }\end{array}$ & $\begin{array}{l}\text { Controlled experiment and } \\
\text { experimental economics for } \\
\text { the evaluation of process } \\
\text { alternatives }\end{array}$ & $\begin{array}{l}\text { Improvement of the } \\
\text { process as a tool intended } \\
\text { to generate performance }\end{array}$ \\
\hline Yen, 2009 & $\begin{array}{l}\text { Integrated model for } \\
\text { business process } \\
\text { measurement }\end{array}$ & $\begin{array}{l}\text { Developed cumulative } \\
\text { measure for business } \\
\text { process evaluation }\end{array}$ & $\begin{array}{l}\text { Analytic hierarchy process } \\
\text { methodology }\end{array}$ & $\begin{array}{ll}\text { Business } & \text { process } \\
\text { performance } & \\
\text { measurement } & \\
\end{array}$ \\
\hline Zhu et al., 2014 & $\begin{array}{l}\text { Location-awareness } \\
\text { approach to the context- } \\
\text { aware business process } \\
\text { modeling }\end{array}$ & $\begin{array}{l}\text { Design specifications for } \\
\text { location-aware process } \\
\text { pattern }\end{array}$ & $\begin{array}{l}\text { Business process modeling, } \\
\text { literature analysis }\end{array}$ & $\begin{array}{l}\text { Improvement of the } \\
\text { process as a tool intended } \\
\text { to generate performance }\end{array}$ \\
\hline
\end{tabular}


The International Journal

ENTREPRENEURSHIP AND SUSTAINABILITY ISSUES

ISSN 2345-0282 (online) http://jssidoi.org/jesi/

2018 Volume 6 Number 1 (September)

http://doi.org/10.9770/jesi.2018.6.1(15)

Jolanta ZEMGULIENE, PhD is the Associate Professor at Business Department, Faculty of Economics and Business Administration, Vilnius University, Lithuania. Research interests: business process management, sustainability of service business.

ORCID ID: orcid.org/0000-0002-6085-4046

Mantas VALUKONIS, PhD is the Assistant Professor at Institute of Economics, Finance and Management, Kaunas Faculty, Vilnius University, Lithuania. Research interests: business sustainability and risk management, financial markets.

ORCID ID: orcid.org/0000-0002-0076-8891

Register for an ORCID ID:

https://orcid.org/register

Copyright (C) 2018 by author(s) and VsI Entrepreneurship and Sustainability Center

This work is licensed under the Creative Commons Attribution International License (CC BY).

http://creativecommons.org/licenses/by/4.0/

cC) (7) Open Access 